\title{
Article \\ Strain-, Sex-, and Time-Dependent Antidepressant-like Effects of Cannabidiol
}

\author{
Gabriela P. Silote ${ }^{1,2} \mathbb{D}$, Michelle C. Gatto ${ }^{1}$, Amanda Eskelund ${ }^{2}$, Francisco S. Guimarães ${ }^{3,4}$, Gregers Wegener ${ }^{2, * \mathbb{D}}$ \\ and Sâmia R. L. Joca $1,5, *$ \\ 1 Department of Biomolecular Sciences, School of Pharmaceutical Sciences of Ribeirão Preto (FCFRP), \\ University of São Paulo (USP), Ribeirão Preto 14040-903, SP, Brazil; gabrielasilote@gmail.com (G.P.S.); \\ michelle.gatto@hotmail.com (M.C.G.) \\ 2 Translational Neuropsychiatry Unit (TNU), Department of Clinical Medicine, Aarhus University, \\ 8000 Aarhus, Denmark; ares@clin.au.dk \\ 3 Department of Pharmacology, School of Medicine of Ribeirão Preto, University of São Paulo, \\ Ribeirão Preto 14049-900, SP, Brazil; fsguimar@fmrp.usp.br \\ 4 Center for Interdisciplinary Research on Applied Neurosciences (NAPNA), University of São Paulo, \\ São Paulo 05508-000, SP, Brazil \\ 5 Department of Biomedicine, Aarhus University, 8000 Aarhus, Denmark \\ * Correspondence: wegener@clin.au.dk (G.W.); sjoca@biomed.au.dk (S.R.L.J.)
}

Citation: Silote, G.P.; Gatto, M.C.; Eskelund, A.; Guimarães, F.S.; Wegener, G.; Joca, S.R.L. Strain-, Sex-, and Time-Dependent Antidepressant-like Effects of Cannabidiol. Pharmaceuticals 2021, 14, 1269. https://doi.org/10.3390/ ph14121269

Academic Editor: Karolina Pytka

Received: 19 October 2021

Accepted: 9 November 2021

Published: 6 December 2021

Publisher's Note: MDPI stays neutral with regard to jurisdictional claims in published maps and institutional affiliations.

Copyright: (c) 2021 by the authors. Licensee MDPI, Basel, Switzerland. This article is an open access article distributed under the terms and conditions of the Creative Commons Attribution (CC BY) license (https:/ / creativecommons.org/licenses/by/ $4.0 /)$.
Abstract: Cannabidiol (CBD) is a non-intoxicating compound extracted from Cannabis sativa, showing antidepressant-like effects in different rodent models. However, inconsistent results have been described depending on the species and the strain used to assess depressive-like behavior. Moreover, only a few studies investigated the effect of CBD in female rodents. Therefore, we aimed to (i) investigate the effects of CBD in two different strains of mice (Swiss and C57BL/6) and a rat model of depression based on selective breeding (Flinders Sensitive and Resistant Lines, FSL and FRL) subjected to tests predictive of antidepressant-like effects and (ii) investigate the influence of sex in the effects of CBD in both mice and rats. CBD induced an antidepressant-like effect in male Swiss but not in female Swiss or C57BL/ 6 mice in the tail suspension test (TST). In male FSL rats, CBD produced an antidepressant-like effect $1 \mathrm{~h}$ post injection. However, in female FSL, CBD induced a bimodal effect, increasing the immobility time at $1 \mathrm{~h}$ and decreasing it at $2 \mathrm{~h}$. In conclusion, strain, sex, and administration time affect CBD's behavioral response to rodents exposed to tests predictive of antidepressant effects.

Keywords: cannabidiol; S-ketamine; sex; mice strain; Flinders Sensitive Line rats; Flinders Resistant Lines rats; tail suspension test; forced swim test

\section{Introduction}

Major depressive disorder (MDD) is a chronic and disabling psychiatric disorder [1]. The World Health Organization (WHO) estimates that more than 300 million people suffer from depression worldwide [2,3] and that MDD is a major contributor to the world's burden of disease $[4,5]$. This scenario is further aggravated by the high prevalence and comorbidity of anxiety disorders, affecting more than 3.6\% of the world population [2]. Consequently, there is a significant socioeconomic impact with increasing health-related costs and a reduction in the productivity of the economically active population [6,7]. Importantly, there is a considerable sex imbalance in MDD and anxiety prevalence, with depression being twice as prevalent in women than men [2,3]. Despite that, the use of females to investigate new drugs and neuropathology is scarce in basic research [8-10]. Eighty percent of the preclinical research in behavioral neuroscience has been developed in male subjects [11], which can potentially limit the benefit of the discoveries for females and compromise the development of personalized medicine [8,11-13]. 
Cannabidiol (CBD) is one of the main active constituents present in Cannabis sativa [14]. Unlike delta-9-tetrahydrocannabinol ( $\triangle 9$-THC), it does not induce psychostimulant effects, nor is it associated with an increased risk of abuse and dependence [15]. Due to its nonintoxicating properties and multitargeted action $[16,17]$, the therapeutic properties of CBD were investigated in several animal models of neurological and psychiatric disorders, with promising results [18]. The anxiolytic effect of CBD was shown in different animal models [19-21] and clinical trials [19-21]. Although consistent data from humans are still lacking [16], the antidepressant properties of CBD were consistently demonstrated in different behavioral readouts, such as the Forced Swim Test (FST) [22-26], Tail Suspension Test (TST) [27], Learned Helplessness (LH) [24], Olfactory Bulbectomy (OBX) [28], and Chronic Unpredictable Mild Stress (CUMS) [29,30]. Moreover, CBD is also able to rescue the behavioral phenotype of congenitally depressed rat strains, such as the Wistar-Kyoto (WKY) [31,32] and Flinders Sensitive Line (FSL) rats [24,32]. Interestingly, CBD produces a rapid and sustained antidepressant-like effect in rodents, similar to ketamine [24]. This characteristic places CBD as an interesting new drug to successfully treat depression and anxiety.

However, most studies investigating CBD antidepressant effects were performed in male rodents [16]. More recently, Shbiro and colleagues [32] investigated the effects of CBD in both female and male WKY and FSL rats and reported that CBD induced antidepressantlike effects in male and female WKY and male FSL rats [32]. However, in this study, the authors investigated only one dose of CBD $(30 \mathrm{mg} / \mathrm{kg})$, making it difficult to conclude that CBD lacks effects in female FSL rats, since this drug is known to produce an inverted U-shape dose-response curve [24,26,33,34]. Moreover, significant variability in effective CBD doses were observed (10-200 mg/ $\mathrm{kg}$ ), depending on the rodent species and strain, treatment time, and test used (reviewed by [16]). Indeed, a growing body of evidence suggests that strain and species of the selected rodents may affect baseline behavioral measurements in distinct paradigms [35-41]. These factors may also influence the drug response, interfering with the effective dose range [36,37,40,42] or causing the absence of effect in different tests $[37,38,43]$.

Therefore, we examined CBD anxiolytic and antidepressant-like effects in both sexes of different rodent species (rats and mice). More specifically, the present study aimed to investigate whether CBD treatment could produce (i) an anxiolytic and antidepressantlike effect in male and female Swiss and C57BL/ 6 mice (the two most-used mice strains) submitted to TST and elevated plus maze (EPM) and (ii) an antidepressant-like effect in male and female FSL rats exposed to FST at different time points ( 1 and $2 \mathrm{~h}$ before the test).

\section{Results}

\subsection{Swiss and C57BL/6 Mice}

CBD Effects in Male and Female Swiss and C57BL/6 Mice Submitted to the Elevated Plus Maze (EPM) and Tail Suspension Test (TST)

A three-way ANOVA was performed to examine the effects on mice (Swiss and C57BL/6) of treatment, sex, and strain on the parameters evaluated in the TST and EPM. There was a significant effect of the treatment (three-way ANOVA: $\mathrm{F}(4,141)=7.69 ; p<0.001$ ) and mice strain on immobility in the TST (three-way ANOVA: $\mathrm{F}(4,141)=289.7 ; p<0.001$ ). Swiss mice presented greater immobility compared to C57BL/ 6 mice. Moreover, there was an interaction between treatment vs. $\operatorname{sex}(\mathrm{F}(4,141)=3.31 ; p=0.013)$ and a statistical tendency in the interaction treatment vs. strain $(\mathrm{F}(4,141)=2.21 ; p=0.07)$.

Since there was a significant effect on the strain and a tendency in the interaction (treatment vs. strain), we performed an independent two-way ANOVA to evaluate the treatment and sex effects in each mice strain, Swiss and C57BL/6. In Swiss mice, the two-way ANOVA revealed a significant effect of the treatment $(\mathrm{F}(4,56)=5.21 ; p=0.001)$ and the interaction (sex vs. treatment; $\mathrm{F}(4,56)=2.54 ; p=0.05$ ). Afterwards, a one-way ANOVA was performed on each sex to compare the treatment effect on immobility. In male Swiss mice, a single injection of imipramine (IMIP) and all doses of CBD decreased 
immobility time in the TST (one-way ANOVA: $\mathrm{F}(4,25)=8657 ; p=0.0002$; Dunnett test: IMIP, $p<0.0001 ;$ CBD $3 \mathrm{mg} / \mathrm{kg}, p=0.0159 ; \mathrm{CBD} 10 \mathrm{mg} / \mathrm{kg}, p=0.0038 ; \mathrm{CBD} 30 \mathrm{mg} / \mathrm{kg}$, $p=0.0182$; Cohen test: VEH vs. IMIP: $\mathrm{d}=3.983$; VEH vs. CBD groups: $\mathrm{f}=0.70$; Figure $1 \mathrm{~B}$ ), suggesting an antidepressant-like effect. However, none of the drug treatments modified the analyzed parameters in female Swiss mice (Kruskal-Wallis test: $\mathrm{H}(5)=6.153 ; p=0.188$; Figure 2B). A two-way ANOVA showed no effect on C57BL/6 mice (Figures 3B and 4B).

Regarding the anxiety-related behavior assessed in the EPM, a three-way ANOVA revealed a significant strain effect (three-way ANOVA: $\mathrm{F}(1,150)=22.43 ; p<0.001$ ), interaction sex vs. strain (three-way ANOVA: $\mathrm{F}(1,141)=7.84 ; p<0.001$ ), and no treatment effect on the OA entries, revealing that C57BL/ 6 mice explored OA more than Swiss mice. The difference was more significant in male than female animals. Moreover, there was significant sex vs. strain interaction in the percentage of time spent in the OA (three-way ANOVA: $F(1,151)=10.74 ; p=0.001)$, revealing that male Swiss mice spent less time exploring the OA than their female counterparts. In C57BL/ 6 mice, the exploratory response was similar between sexes (Figure 1E, Figure 2E, Figure 3E, Figure 4E).

Furthermore, in the time spent in the OA, a three-way ANOVA revealed a significant difference in the sex (three-way ANOVA: $\mathrm{F}(1,148)=12.84 ; p<0.001$ ), strain (three-way ANOVA: $\mathrm{F}(1,148)=9.58 ; p<0.001$ ), and the treatment vs. strain interaction (three-way ANOVA: $F(1,148)=2.80 ; p=0.028)$, demonstrating that female mice spent more time exploring the OA compared to males. Following the significant treatment vs. strain interaction, we performed a two-way ANOVA to evaluate the treatment and strain effects in Swiss and C57BL/ 6 mice. There was no difference in C57BL/6 mice (Figures 3 and 4). On the other hand, there was a significant treatment effect on the OA of the Swiss mice (two-way ANOVA: F $(4,73)=4.08 ; p=0.005)$. However, a one-way ANOVA or KruskalWallis in each sex of the Swiss mice failed to find a significant effect in this parameter (male: Kruskal-Wallis test: $\mathrm{H}(5)=4.792 ; p=0.3094$; Figure 1D; female: one-way ANOVA: F(4, 148) $=1.646 ; p=0.1862$; Figure 2D).

Concerning the EA entries, a three-way ANOVA revealed a significant treatment effect in this behavioral response $(F(4,148)=5.85 ; p=0.001)$. Only in female Swiss mice, imipramine and CBD $10 \mathrm{mg} / \mathrm{kg}$ treatment reduced the EA entries in the EPM compared to VEH-treated mice (one-way ANOVA: F $(4,33)=8.305 ; p<0.001$; Dunnett test: IMIP, $p=0.0054 ;$ CBD $10 \mathrm{mg} / \mathrm{kg}, p=0.0310$; Figure $2 \mathrm{~F}$ ). There was no significant correlation between immobility time and EA entries in the IMIP and CBD $10 \mathrm{mg} / \mathrm{kg}$ treated group (correlation: IMIP, $\mathrm{r}=-0.5697 ; p=0.1405 ; \mathrm{CBD} 10, \mathrm{r}=0.1224 ; p=0.7937$; data not shown). Therefore, the alteration in the locomotor activity did not affect the immobility in the TST. There was no statistical difference in male Swiss (Figure 1F) and C57BJ/6 mice of both sexes (male: Figure 3F; female: Figure 4F).

In summary, CBD induced an antidepressant-like effect in male Swiss mice without affecting the locomotor activity, but not in females from the same strain. Moreover, CBD did not affect the TST and EPM behaviors in male and female C57BL/ 6 mice. 

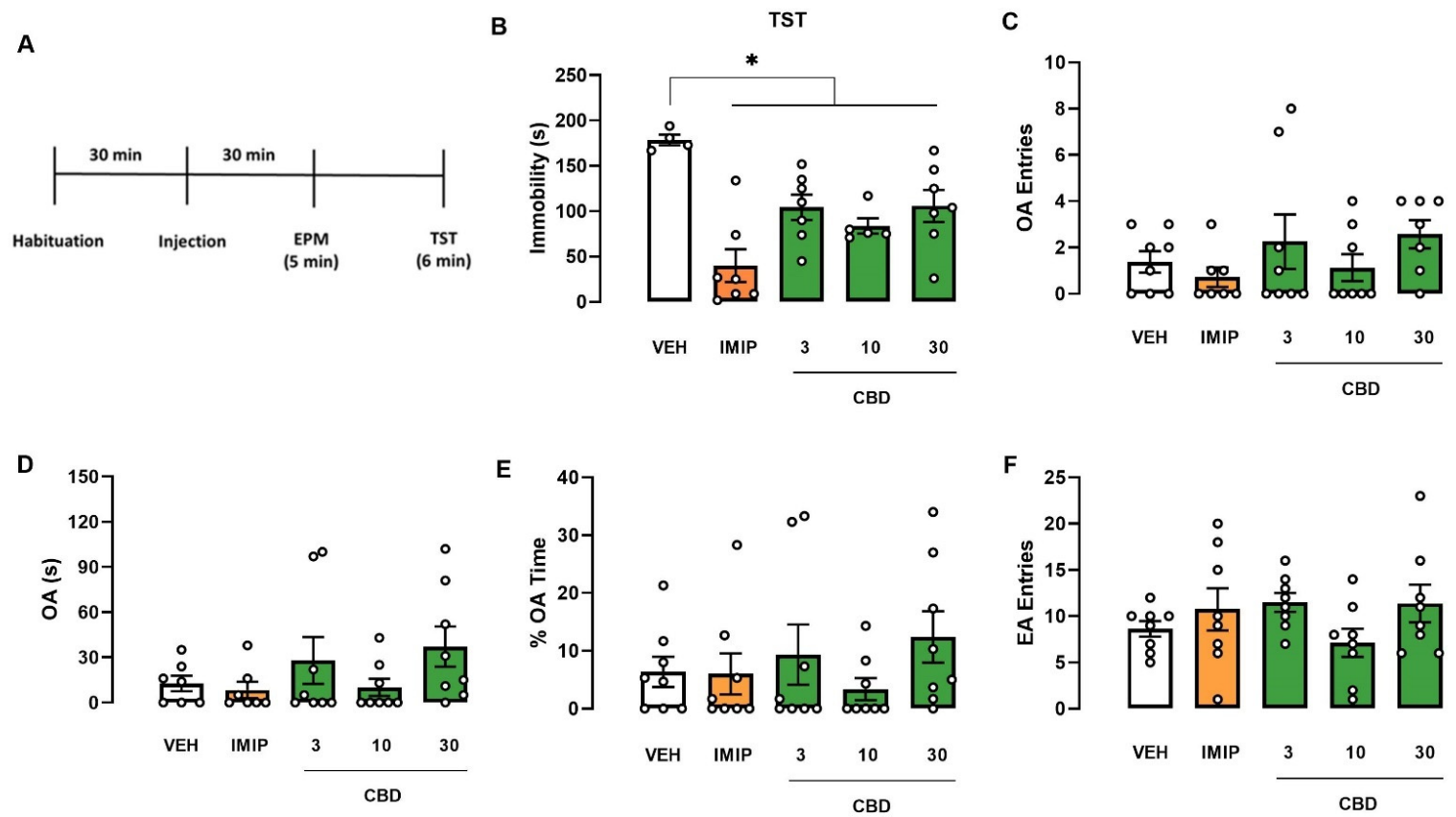

Figure 1. Effects induced by cannabidiol (CBD) in male Swiss mice submitted to tail suspension test and elevated plus-maze. Experimental scheme (A). Effect of cannabidiol (CBD) in male Swiss mice administered 30 min before the exposure to TST (B). EPM (C-F). Bars represent the immobility time (s) in the TST, time and percentage of the time spent on OA, number of $\mathrm{OA}$ and EA entries in the EPM. Values are mean \pm SEM; asterisk represents significant treatment difference from control ( ${ }^{*} p<0.05$; one-way ANOVA followed by Dunnett post hoc test), $\mathrm{n}=4-8$ animals/group. CBD: cannabidiol; EA: enclosed arm; IMIP: imipramine; OA: open arm; VEH: vehicle.
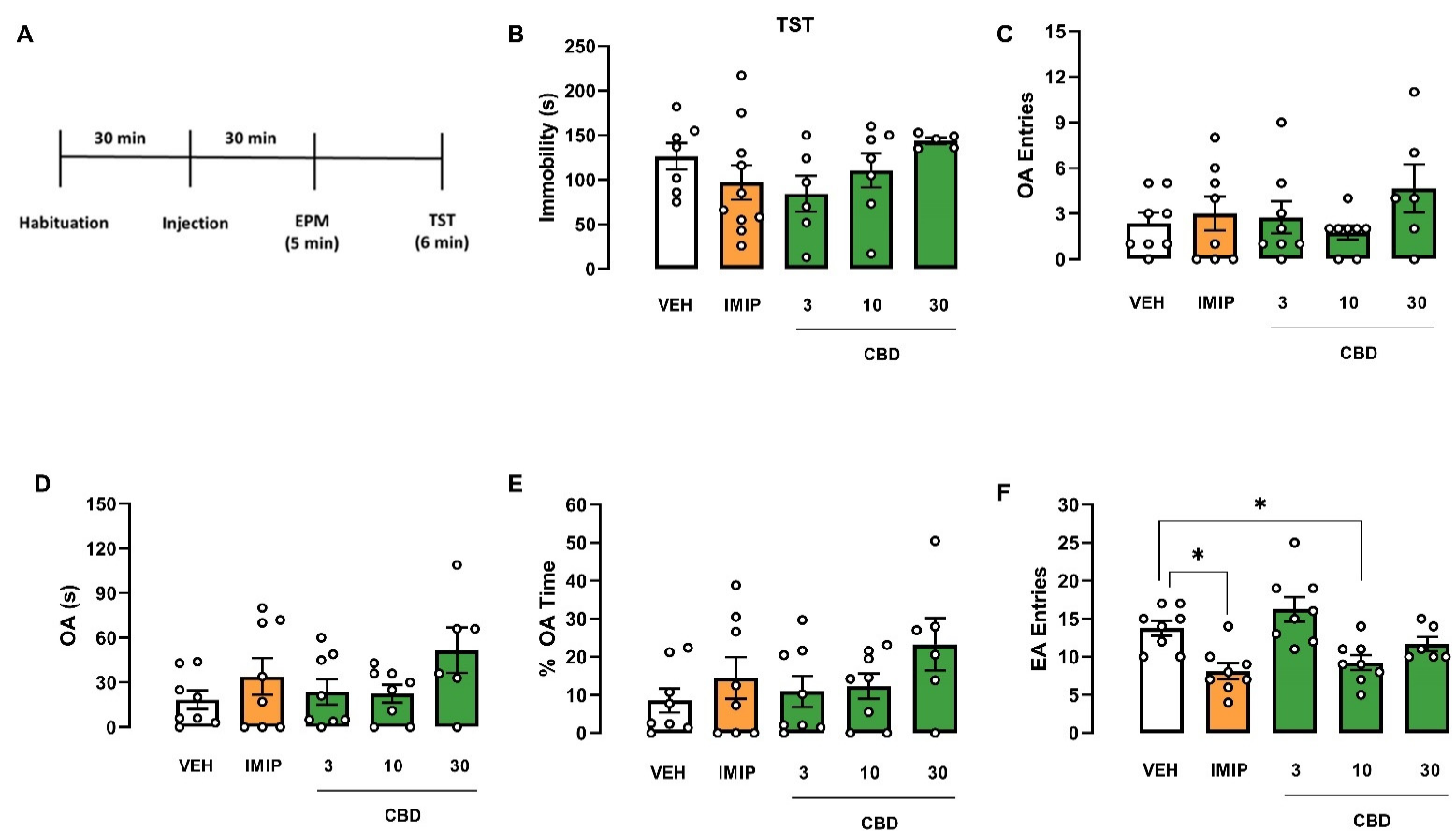

Figure 2. Effects induced by cannabidiol (CBD) in female Swiss mice submitted to the tail suspension test and elevated plus maze. Experimental scheme (A). Effect of cannabidiol (CBD) in female Swiss mice administered 30 min before the exposure to the TST (B) and EPM (C-F). Bars represent the immobility time (s) in the TST, time and percentage of the time spent on $\mathrm{OA}$, number of OA and EA entries in the EPM. Values are mean \pm SEM; asterisk represents significant treatment difference from control (* $p<0.05$; one-way ANOVA followed by Dunnett post hoc test), $\mathrm{n}=5-10$ animals/group. CBD: cannabidiol; EA: enclosed arm; IMIP: imipramine; OA: open arm; VEH: vehicle. 


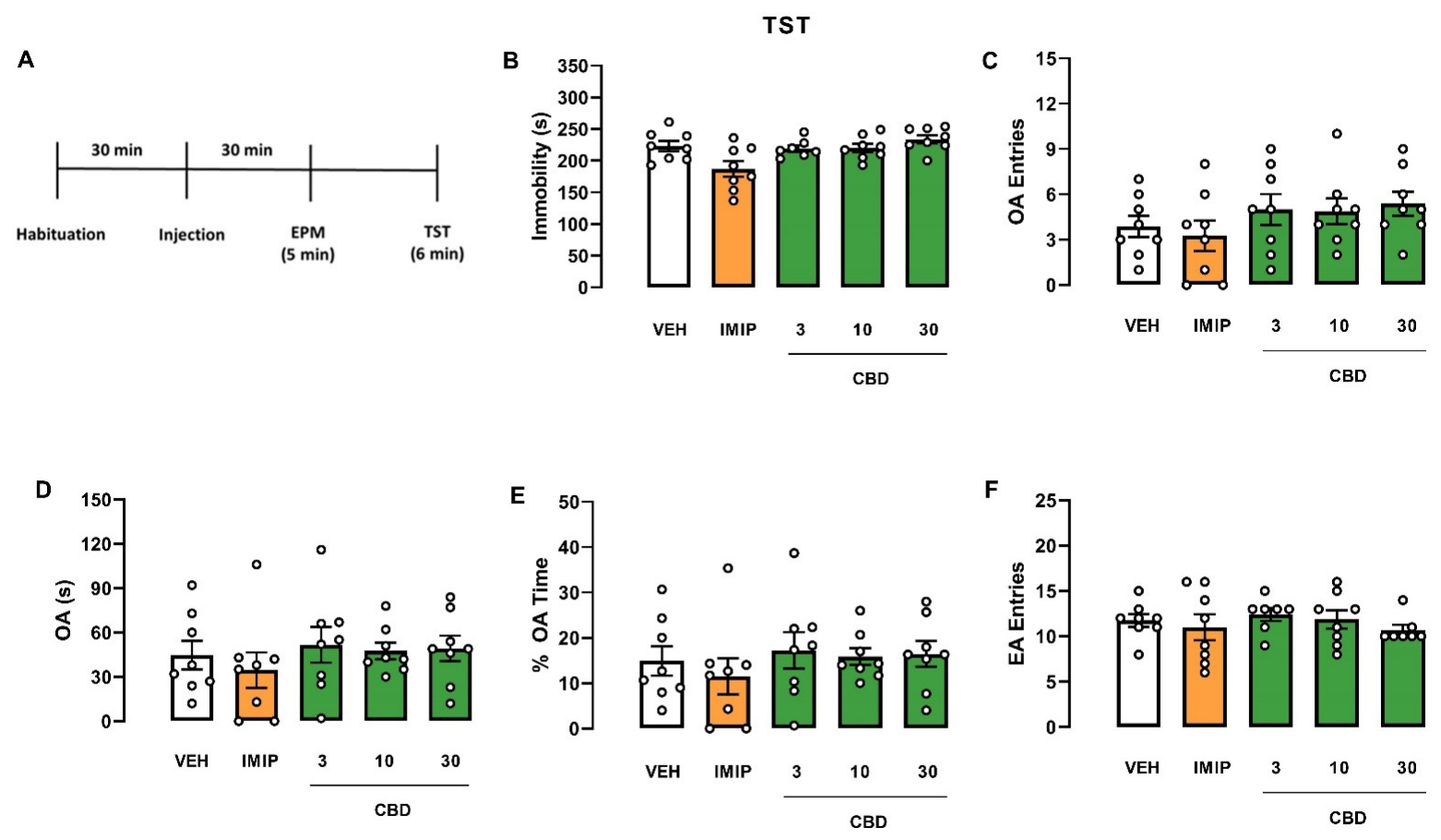

Figure 3. Effects induced by cannabidiol (CBD) in male C57BL/ 6 mice submitted to the tail suspension test and elevated plus maze. Experimental scheme (A). Effect of cannabidiol (CBD) in male C57BL/6 mice administered 30 min before the exposure to the TST (B) and EPM (C-F). Bars represent the immobility time (s) in the TST, time and percentage of the time spent on OA, number of OA and EA entries in the EPM. Values are mean \pm SEM; $n=7-8$ animals/group. CBD: cannabidiol; EA: enclosed arm; IMIP: imipramine; OA: open arm; VEH: vehicle.

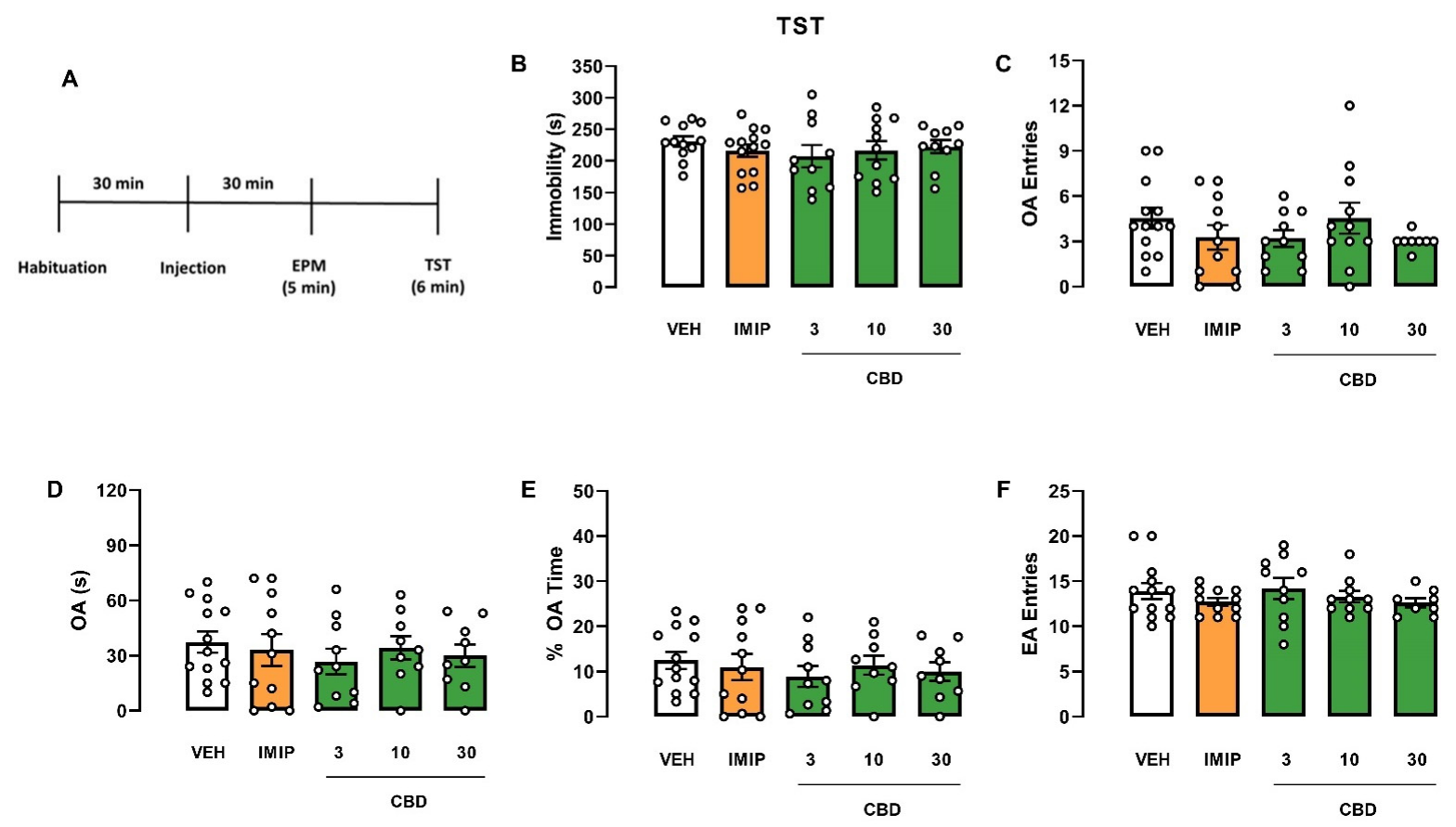

Figure 4. Effects induced by cannabidiol (CBD) in female C57BL/ 6 mice submitted to the tail suspension test and elevated plus maze. Experimental scheme (A). Effect of cannabidiol (CBD) in female C57BL/ 6 mice administered 30 min before the exposure to TST (A) and EPM (B-F). Bars represent the immobility time (s) in the TST, time and percentage of the time spent on OA, number of OA and EA entries in the EPM. Values are mean \pm SEM; $\mathrm{n}=9-13$ animals/group. CBD: cannabidiol; EA: enclosed arm; IMIP: imipramine; OA: open arm; VEH: vehicle. 


\subsection{FSL Rats}

\subsubsection{Dose-Response Curve of Ketamine in Female FSL Rats Exposed to the OFT/FST}

As expected, ketamine $15 \mathrm{mg} / \mathrm{kg}$ and $20 \mathrm{mg} / \mathrm{kg}$ reduced the immobility in FSL rats exposed to the FST (Kruskal-Wallis test: $\mathrm{H}(4)=10.60 ; p=0.0141$; Dunn's and Cohen $\mathrm{d}$ tests: ketamine $15 \mathrm{mg} / \mathrm{kg}, p=0.0198, \mathrm{~d}=1.838$; ketamine $20 \mathrm{mg} / \mathrm{kg}, p=0.0108, \mathrm{~d}=3.350$; Figure 5B). FSL rats treated with vehicle had significantly higher immobility time when compared with FRL rats treated with vehicle (Mann-Whitney test: $\mathrm{U}=6.5 ; p=0.0037$; Figure 5B), which characterized a depressive-like phenotype. Neither rat strain (Student's $t$-test: $\mathrm{t}(15)=0.7981 ; p=0.4373$ ) nor drug treatment (one-way ANOVA: $\mathrm{F}(3,24)=0.6495$; $p=0.5910$; Figure 5C) changed the OFT locomotor activity in FSL rats.
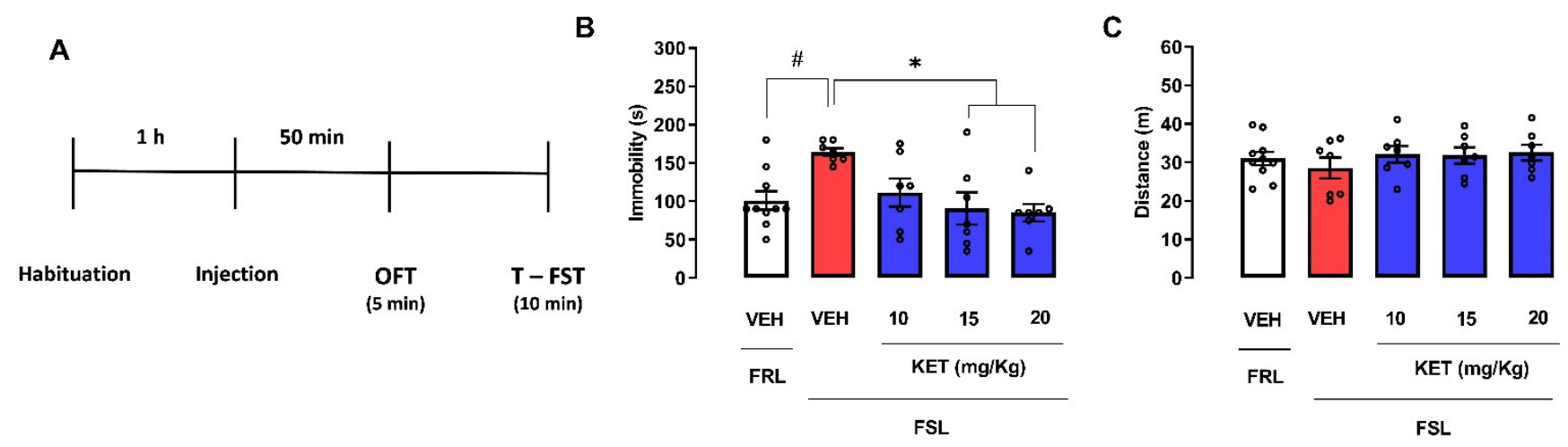

Figure 5. Dose-response curve of S-ketamine in female FSL rats submitted to the forced swim and open field tests. Experimental scheme (A). The rats were treated with VEH or ketamine (10, 15, and $20 \mathrm{mg} / \mathrm{kg}) 1 \mathrm{~h}$ before the exposition to the FST (B) and OFT (C). Bars represent the immobility time (s) in the FST or the traveled distance (m) in the OFT. Values are mean \pm SEM; hash indicates significant differences between FSL and FRL vehicle-treated groups (\# $p<0.05$, Student's $t$-test or Mann-Whitney test); asterisk represents significant treatment difference from FSL control $\left({ }^{*} p<0.05\right.$; Kruskal-Wallis followed by Dunn's post hoc), $\mathrm{n}=7-10$ animals/group. FST: forced swimming test; OFT: open field test; KET: S-ketamine; VEH: vehicle.

\subsubsection{Effect Produced by CBD Administered 1 or $2 \mathrm{~h}$ before the OFT/FST in Male and Female FSL Rats}

A three-way ANOVA was performed to examine the effect of treatment, sex, and time in the parameters evaluated in the FST and OFT. There was a significant effect of treatment (three-way ANOVA: $\mathrm{F}(4,94)=10.29 ; p<0.001$ ) and sex (three-way ANOVA: $\mathrm{F}(1,94)=25.48$; $p<0.001$ ) and between treatment vs. time (three-way ANOVA: $\mathrm{F}(2,94)=3.82 ; p=0.025$ ), sex vs. time (three-way ANOVA: $\mathrm{F}(1,94)=28.53 ; p<0.001$ ), and treatment vs. sex vs. time (three-way ANOVA: $\mathrm{F}(2,94)=15.41 ; p<0.001)$ interactions in the immobility in the FST.

Furthermore, in the total distance traveled in the OFT, there was a significant effect of treatment (three-way ANOVA: $\mathrm{F}(4,94)=12.80 ; p<0.001$ ), sex (three-way ANOVA: $\mathrm{F}(1,94)$ $=38.16 ; p<0.001$ ), and time (three-way ANOVA: $\mathrm{F}(1,94)=7.32 ; p<0.001$ ) and treatment vs. sex (three-way ANOVA: $\mathrm{F}(4,94)=13.58 ; p<0.001$ ), treatment vs. time (three-way ANOVA: $\mathrm{F}(2,94)=3.96 ; p=0.022)$, sex vs. time (three-way ANOVA: $\mathrm{F}(4,94)=4.27 ; p=0.04)$, and treatment vs. sex vs. time (three-way ANOVA: $\mathrm{F}(2,94)=7.46 ; p=0.0001$ ) interactions.

Since there was a significant effect in the interaction (treatment vs. sex vs. time) in the parameters assessed in FST and OFT, we performed an independent Student's $t$-test to compare the results between the rat strains, FRL and FSL, vehicle-treated groups, and a one-way ANOVA followed by Dunnett post hoc test to evaluate the treatment effect in each sex and time in FSL rats. When the variances between the groups were not homogenous, the Mann-Whitney (for comparisons between FSL and FRL vehicle-treated groups) or Kruskal-Wallis followed by Dunn's post hoc tests were used to compare FSL rats treated with VEH, ketamine, or CBD. 
One hour after injection, male FSL rats treated with vehicle displayed significantly increased immobility time compared with FRL rats treated with vehicle (Student's $t$-test: $t(17)$ $=5.126 ; p<0.0001$; Figure 6 C $)$. FSL rats treated with CBD $(30 \mathrm{mg} / \mathrm{kg})$ or KET $(15 \mathrm{mg} / \mathrm{kg})$ showed a tendency to reduce immobility time (one-way ANOVA: $\mathrm{F}(4,29)=3.178 ; p=0.0279$; Dunnett test: CBD $30 \mathrm{mg} / \mathrm{kg}, p=0.0826$; KET, $p=0.0523$; Cohen d test: FSL-VEH vs. FSL$\mathrm{KET}, \mathrm{d}=1.218$; FSL-VEH vs. FSL-CBD $30 \mathrm{mg} / \mathrm{kg}, \mathrm{d}=1.153$; Figure 6C), suggesting an antidepressant-like effect. Neither rat strain $(\mathrm{t}(17)=0.5769 ; p=0.5716)$ nor drug treatment (one-way ANOVA: F $(4,29)=0.3576 ; p=0.8366$; Figure $6 \mathrm{E}$ ) changed the locomotor activity in FSL rats.

Two hours after injection, male FRL treated with vehicle presented lower immobility (Student's t-test: $\mathrm{t}(16)=5.241 ; p<0.0001$; Figure 6D) and increased locomotion (Student's $t$-test: $\mathrm{t}(16)=2.722 ; p=0.0151$; Figure $6 \mathrm{~F}$ ) in comparison with vehicle-treated FSL animals. As demonstrated previously, ketamine $(15 \mathrm{mg} / \mathrm{kg})$ injected $1 \mathrm{~h}$ before FST reduced immobility in FSL rats (Kruskal-Wallis test: $\mathrm{H}(3)=14.52 ; p=0.0007$; Dunn's test: $p=0.0007$; Cohen $\mathrm{d}$ test: $\mathrm{d}=1.749$; Figure $6 \mathrm{D})$. CBD did not change immobility in the test $2 \mathrm{~h}$ later (Kruskal-Wallis test: $\mathrm{H}(3)=14.52 ; p=0.0007$; Dunn's: $p>0.9999$; Figure 6D). None of the treatments changed the distance traveled in the OFT (one-way ANOVA: F(2, 27) = 0.3255; $p=0.7250$; Figure $6 \mathrm{~F}$ ).

On the other hand, female FSL rats treated with vehicle displayed significantly increased immobility time when compared with FRL rats treated with vehicle (Student's $t$-test: $t(12)=2.954 ; p=0.0120$; Figure $7 \mathrm{C}$ ). They also showed a significant decrease in locomotion (Mann-Whitney test: $\mathrm{U}=8 ; p=0.0426$; Figure 7E). However, female FSL rats treated with the intermediate dose of CBD $(30 \mathrm{mg} / \mathrm{kg})$ showed a tendency to increase immobility in the FST $1 \mathrm{~h}$ after treatment (one-way ANOVA: $\mathrm{F}(4,24)=9.464 ; p<0.0001$; Dunnett test: $p=0.0898$; Figure 7C), suggesting a depressive-like effect. In contrast, the FSL rats treated with ketamine $(20 \mathrm{mg} / \mathrm{kg})$ showed a significant reduction the immobility (one-way ANOVA: F(4, 24) = 9.464; $p<0.0001$; Dunnett test: $p=0.0096$; Figure 7C). No drug treatment in FSL rats affected the locomotor activity (Kruskal-Wallis test: $\mathrm{H}(5)=5.917$; $p=0.2054$; Figure 7E).

Two hours after injection, female FSL rats treated with vehicle displayed significantly increased immobility time when compared with FRL rats treated with vehicle (Student's $t$-test: $(\mathrm{t}(8)=3.076 ; p=0.0152$; Figure 7D). They also presented a tendency to decrease the distance traveled in OFT $(\mathrm{t}(8)=1.861 ; p=0.0998$; Figure 7D). Interestingly, $2 \mathrm{~h}$ after treatment CBD $(30 \mathrm{mg} / \mathrm{kg})$ in female FSL rats, immobility was reduced (one-way ANOVA: $\mathrm{F}(2,15)=4.439 ; p=0.0306$; Dunnett test: $p=0.018$; Cohen $\mathrm{d}$ test: $\mathrm{d}=1.621$; Figure 7D). Ketamine $(20 \mathrm{mg} / \mathrm{kg})$ injected $2 \mathrm{~h}$ before the FST did not change the behavior in the test (one-way ANOVA: $\mathrm{F}(2,15)=4.439 ; p=0.0306$; Dunnett test: $p=0.4096$; Figure 7D). No treatment modified the distance traveled in the OFT in FSL rats (one-way ANOVA: F(2, 15) $=0.9503 ; p=0.4087$; Figure 7F). 
A

$$
1 \text { hour }
$$

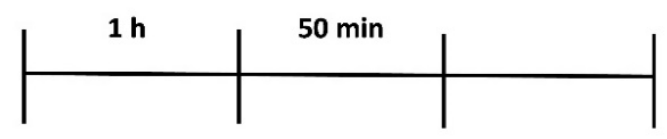

Habituation

$\begin{array}{cc}\text { OFT } & \text { T - FST } \\ (5 \mathrm{~min}) & (10 \mathrm{~min})\end{array}$

$1 \mathrm{~h}$
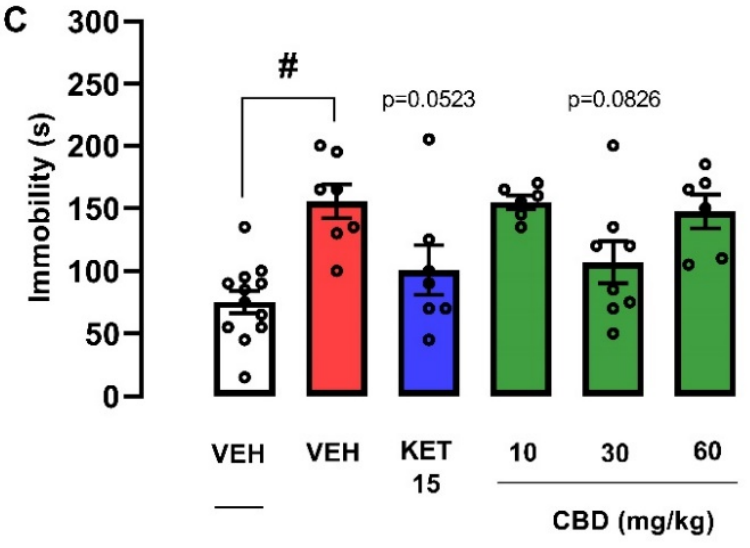

FRL

FSL
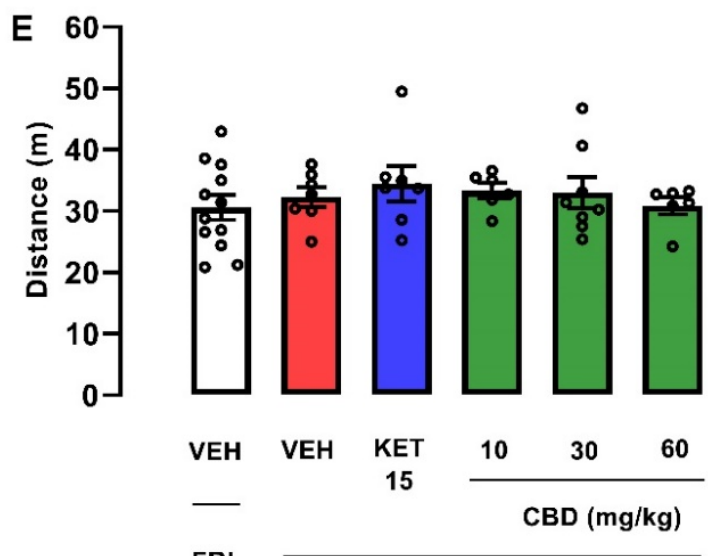

FRL

FSL
B

2 hours

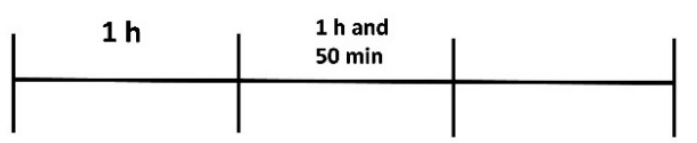

Habituation Injection
F

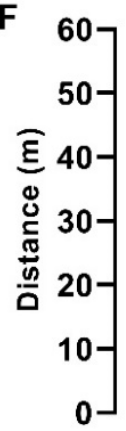

FRL

FSL
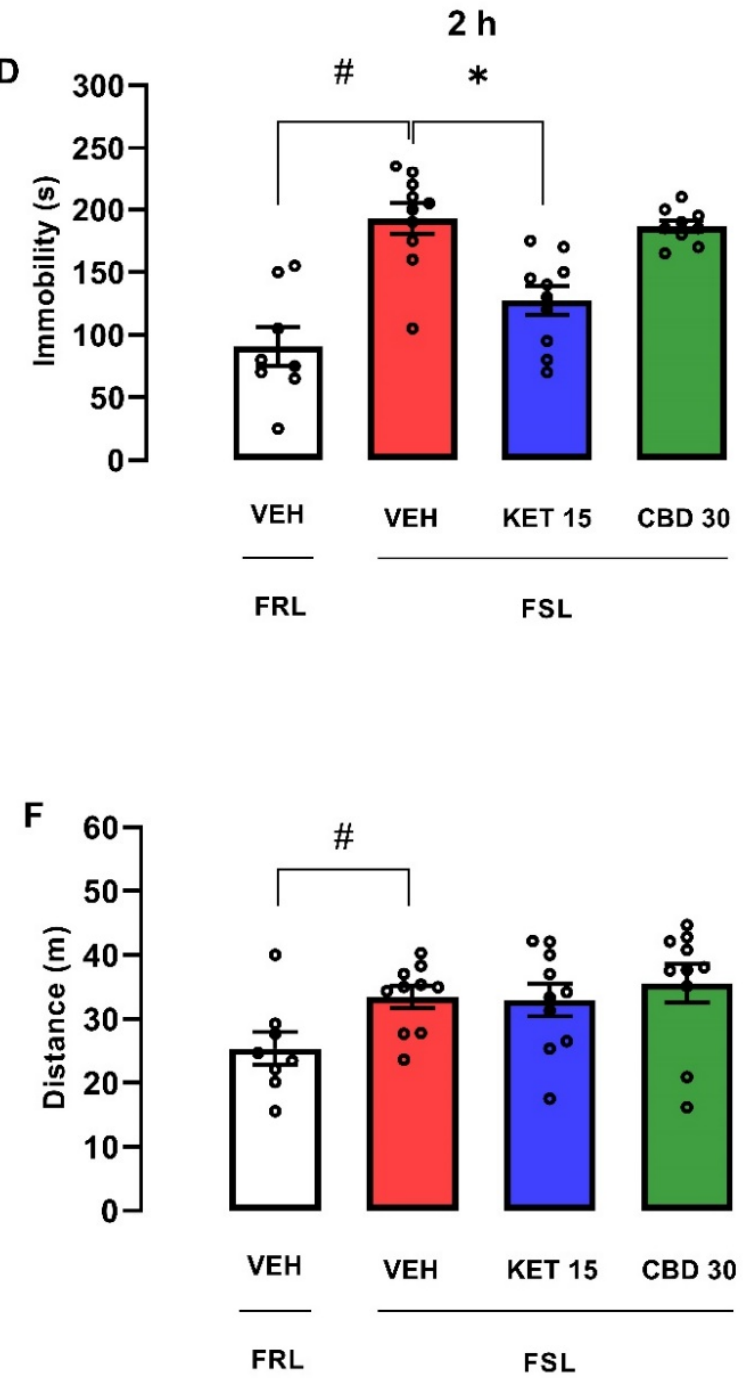

Figure 6. Effects of cannabidiol (CBD) administered 1 or $2 \mathrm{~h}$ before the forced swim and open field tests in male FSL rats. Experimental scheme (A,B). Effect of cannabidiol (CBD) in male FSL rats administered 1 (C,E) or 2 h (D,F) before the FST and OFT. Bars represent the immobility time (s) in FST or the traveled distance (m) in the OFT. Values are mean \pm SEM; hash indicates significant differences between FSL and FRL vehicle-treated groups (\# $p<0.05$, Student's $t$-test); asterisk represents significant treatment difference from FSL control $\left({ }^{*} p<0.05\right.$; one-way ANOVA followed by Dunnett post hoc test or Kruskal-Wallis followed by Dunn's post hoc), $\mathrm{n}=6-12$ animals/group. CBD: cannabidiol; FST: forced swimming test; OFT: open field test; KET: S-ketamine; VEH: vehicle. 
A

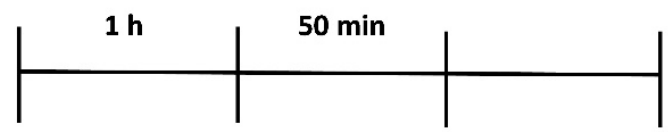

Habituation
1 hour

Injection

$\begin{array}{cc}\text { OFT } & \text { T - FST } \\ \text { (5 min) } & \text { (10 min) }\end{array}$

$1 \mathrm{~h}$
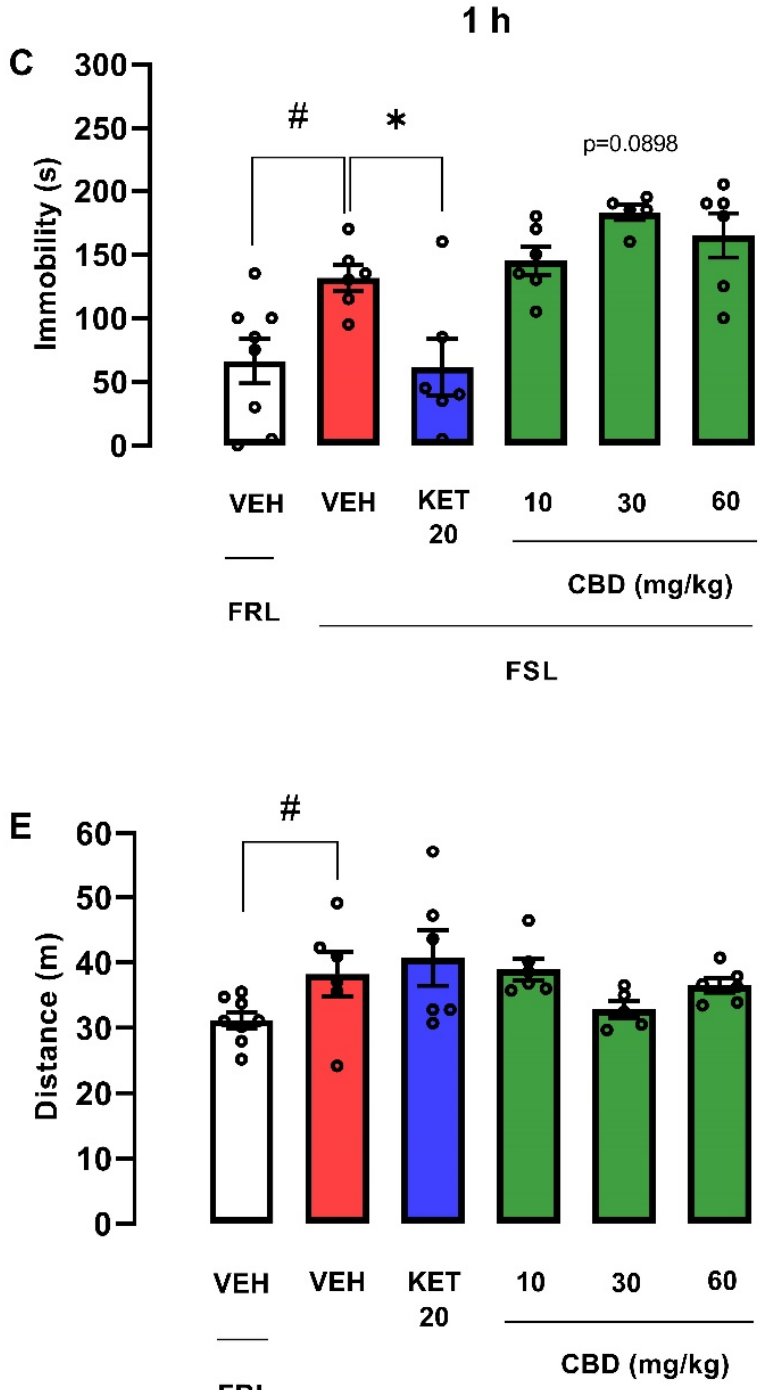

FRL
B

2 hours

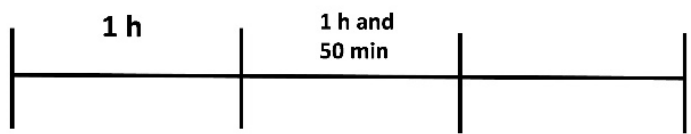

Habituation

Injection

OFT

T - FST

(5 min)

(10 $\mathrm{min}$ )

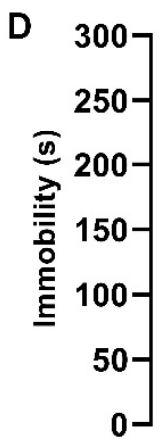

$2 \mathrm{~h}$
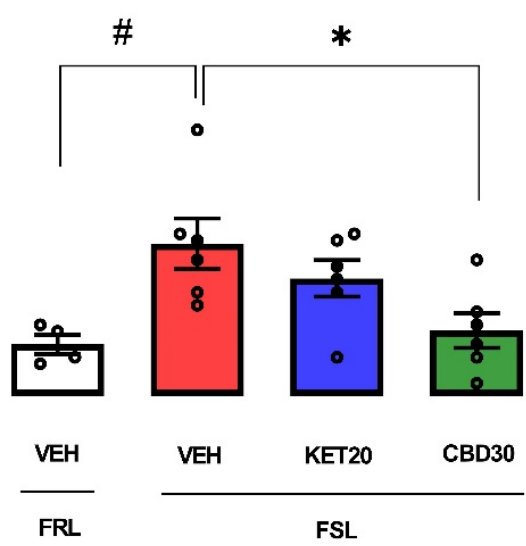

$\mathbf{F}$

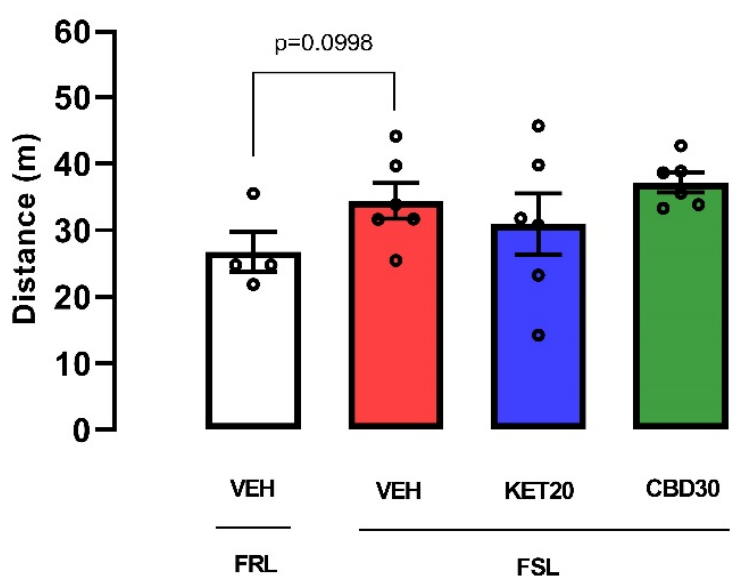

FSL

Figure 7. Effects of cannabidiol (CBD) administered 1 or $2 \mathrm{~h}$ before the forced swim and open field tests in female FSL rats. Experimental scheme (A,B). Effect of cannabidiol (CBD) in female FSL rats administered $1(\mathbf{C}, \mathbf{E})$ and $2 \mathrm{~h}(\mathbf{D}, \mathbf{F})$ before the exposure to the FST and OFT. Bars represent the immobility time (s) in the FST or the traveled distance (m) in the OFT. Values are mean \pm SEM; hash indicates significant differences between FSL and FRL vehicle-treated groups $(\# p<0.05$, Student's $t$-test or Mann-Whitney test); asterisk represent significant treatment difference from FSL control rats $\left({ }^{*} p<0.05\right.$; one-way ANOVA followed by Dunnett post hoc), $\mathrm{n}=4-10$ animals/group. CBD: cannabidiol; FST: forced swimming test; OFT: open field test; KET: S-ketamine; VEH: vehicle. 


\section{Discussion}

The main finding of the present work was that CBD differentially modulates depressivelike behavior depending on injection time, strain, species, and sex. This study was the first to systematically investigate CBD's behavioral effects in both sexes of FSL rats and different mice strains (Swiss and C57BL/6). Our main findings suggest that CBD produces an antidepressant-like effect in male Swiss mice but not in C57BL/6J mice. Strikingly, CBD induced a bimodal effect in female FSL rats depending on the injection time. In contrast, $\mathrm{CBD}$ tended to decrease the immobility time at $1 \mathrm{~h}$ after the injection in males and did not produce any behavioral change at $2 \mathrm{~h}$.

Previous studies reported that acute injection of CBD produces an antidepressant-like effect in male Swiss mice subjected to different predictive tests, including FST [24-26,44] and TST [27], as we also observed herein. However, we failed to find an antidepressant effect of acute CBD treatment in male C57BL/ 6 mice in the TST. Previous studies reported that acute and repeated $\mathrm{CBD}$ administration produced a behavioral response in male C57BL/ 6 mice submitted to OBX [28] and CUMS [45,46], which suggests that CBD effects in C57BL/6J mice might depend on the experimental paradigm and treatment regimen (acute vs. repeated administration). Curiously, imipramine also did not induce an antidepressantlike effect in both male and female C57BL/ 6 mice in the TST, which contrasts with other evidence in the literature [47]. However, it is known that C57BL/ 6 mice are less sensitive than other strains of mice in the TST [38], and experimental conditions, such as age and previous stress exposure [48-51], can affect the results, which might explain the contrasting results between the studies.

On the other hand, CBD did not change the immobility time in female Swiss and C57BL/ 6 mice submitted to the TST. Since CBD was tested in only one time point after drug administration ( $30 \mathrm{~min}$ ) in mice, it is possible that other exposure times could produce different results in female mice, as we observed in female rats. Both pharmacokinetic and pharmacodynamic parameters might have influenced CBD effects in males and females of different mice strains. The peak of maximum plasma concentration (Cmax) of CBD can vary, depending on the route of administration, vehicle used, animal species, and sex [52]. Moreover, evidence has shown that mice strain (Swiss and C57BL/6) influences the baseline behavioral $[38,40,53,54]$ response to established antidepressant drugs $[37,38,40,49,55,56]$, neurochemical profile [37], sensitivity to stress [39,57,58], and some biochemical parameters [39], which could produce a significant impact on the CBD effects. Therefore, experimental differences might have contributed to the contrasting results between studies.

The biological variable sex is a critical factor that affects the antidepressant drug response in different models [37,59-63] and can change the effective dose of a given drug $[36,37,40]$. For example, females may be more sensitive to the effects of selective serotonin reuptake inhibitors (SSRIs), since acute administration of lower doses of fluoxetine [59,61], paroxetine [37], and sertraline [64] produced an antidepressant-like effect in female rats and mice exposed to the FST and TST compared to males. Moreover, similar sex differences were reported in animals with the fast-acting antidepressant drug ketamine [60,65].

Surprisingly, we failed to detect CBD effects in mice submitted to the EPM. This contrasted with previous publications, where the anxiolytic properties of CBD were well described $[27,45,46,54,66]$, but agrees with a recent publication in CD1 mice [67]. The lack of positive control in our EPM studies was a limitation for our conclusions about that. Anxiety disorders are frequently observed as a comorbidity in depressed patients $[68,69]$. However, in contrast to our expectations, CBD did not affect the anxiety-related behaviors in the EPM in male and female mice from both mice strains (Swiss and C57BL/6 mice). Previous works showed similar findings in male C57BL/6J mice, in which CBD acutely administered did not change the anxiety-related behaviors in different tests $[53,54]$.

Moreover, consistent with our results in females, acute and repeated administration of CBD did not produce an anxiolytic effect in adolescent and adult female C57BL/6J 
mice [53]. However, in the OFT and light-dark test, CBD chronic administration did cause an anxiolytic effect after 21 days in male C57BL/6JArc mice [54]. It also prevented (after 14 days) the anxiogenic effect induced by chronic stress in the novelty suppressed feeding and EPM tests [45,46]. Until now, CBD effects on anxiety-related behaviors had not been investigated in female Swiss mice.

In male FSL rats, CBD showed a tendency to induce an antidepressant-like effect $1 \mathrm{~h}$ after the injection in the FST and did not produce any behavioral change $2 \mathrm{~h}$ post injection. A previous study from our group showed that CBD induced an antidepressantlike effect $1 \mathrm{~h}$ after administration but no sustained effect 7 days later in male FSL rats [24]. CBD effect was consistent with previous studies, which reported that CBD acute injection significantly decreased the immobility in the FST $[23,70]$, reduced the number of failures, and increased the number of escapes in LH [24]. The small sample size used herein might have compromised the possibility of detecting a significant effect of $C B D$, although a trend was observed at the dose of $30 \mathrm{mg} / \mathrm{kg}$.

Previous evidence demonstrated that CBD produced a hedonic and antidepressantlike effect in male FSL and WKY rats $2 \mathrm{~h}$ after oral administration, while it had no effect in female FSL [31,32]. In contrast, our results demonstrated a bimodal effect of CBD in female FSL rats, with marked antidepressant effect only at $2 \mathrm{~h}$ post injection. The discrepancy in the behavioral effects can be explained by the different behavioral tests used, vehicle, and the administration routes used (i.p. vs. oral). CBD is a highly lipophilic and poorly soluble molecule, making it difficult to ascertain the correct dose [14,71]. The vehicle and the administration routes can affect its pharmacokinetic profile, thus resulting in different plasma levels, Tmax and Cmax [52,72-74]. Measurements of CBD plasma levels in these two time points clarifying these results.

What could then be the neurobiological explanation behind the sex differences observed in our work? One possible explanation would be the physico-chemical properties of $\mathrm{CBD}$. CBD has a chemical structure that confers high lipophilicity similar to delta-9tetrahydrocannabinol $(\triangle 9-T H C)[14,71]$. Therefore, it rapidly penetrates highly vascularized tissues in a short time, accumulates in fat tissue, and suffers redistribution, modifying the plasmatic concentration of the drug [75]. Consequently, this process can be affected by body weight and composition, which varies between sexes [75-78]. CBD presents a similar molecular structure to $\triangle 9-\mathrm{THC}$ [79-81], and the influence of sex on $\triangle 9$-THC metabolism in the rat liver has been previously shown $[82,83]$. Adult female rats presented higher blood levels of the hydroxylated metabolite, 11-hydroxy- $\triangle 9$-THC, than males [83]. Therefore, it is likely that these factors can influence the plasmatic and brain concentration of CBD and, consequently, differentially impact the behavioral effects observed among different sexes.

Another possible explanation for sex differences could be related to pharmacodynamic aspects. A growing body of evidence has shown sexual dimorphisms in the endocannabinoid and serotonergic systems, key molecular targets enrolled in the CBD effect [16]. For example, the gonadal hormones influence the levels of endocannabinoids [84] and serotonin [85], as well as cannabinoid receptor [86,87] and serotoninergic receptor type $1 \mathrm{~A}$ (5-HT1A) expression $[88,89]$. Indeed, further studies are crucial to understanding the molecular mechanism involved in the CBD effects in females.

The present study was also the first to perform a dose-effect curve for ketamine in female FSL rats. We showed that a single injection of ketamine $(15$ and $20 \mathrm{mg} / \mathrm{kg})$ produced an antidepressant-like effect in female FSL rats exposed to FST. Our finding strengthened previous results showing the efficacy of the treatment with ketamine in female rats, even though the effective doses vary in comparison to males [90-94]. In agreement with these results, our group recently showed that ketamine responses in FSL rats were associated with a sex difference in the hippocampus morphology, alteration of hippocampal astrocytes, and brain-derived neurotrophic factor (BDNF) [95]. More studies are necessary to investigate how these differences are involved in the ketamine effect in female FSL rats.

Notwithstanding, there are a few limitations in the present work. Most importantly, it would be relevant to measure CBD plasma and brain levels in both sexes. It would 
also be interesting to consider the estrous cycle in females and how it may affect the basal response in the tests [96-99]. Even if it seemed not to modulate the FST response in female FSL rats [100], it could influence the drug effects of the other tested species. Due to the limitations of the TST as a model of depression $[47,101]$, it would be interesting to investigate the effect of CBD using additional preclinical models. Finally, a positive control group in the EPM using an anxiolytic benzodiazepine could help to confirm the lack of CBD effect in anxiety-related behaviors in both sexes and strains of the used mice [102-104].

\section{Materials and Methods}

\subsection{Animals}

We used adult male and female Swiss and C57BL/6 mice (8 weeks old) from the University of São Paulo (SP) breeding facility and adult male and female Flinders Sensitive Line (FSL) and Flinders Resistant Line rats (FRL; control of genetic background) (weight: male: 200-405 g; female: 138-216 g; 8-12 weeks old) from breeding colonies at Translational Neuropsychiatry Unit (Aarhus University, Aarhus, Denmark). The mice were housed in groups of 10 animals per polypropylene cages $(200 \times 120 \times 300 \mathrm{~mm})$, and the rats were housed in pairs in standard cages (Cage 1291H Eurostandard Type III H, $425 \times 266 \times$ $185 \mathrm{~mm}$, Tecniplast, Buguggiate, VA, Italy). All animals were housed in a temperaturecontrolled room $\left(23 \pm 2{ }^{\circ} \mathrm{C}\right)$ with a $12 / 12 \mathrm{~h}$ light-dark cycle (lights on 6:00 a.m./lights off 6:00 p.m.) with free access to tap water and standard food. The bedding material for rats (Tapvei Estonia OÜ, Paekna, Estonia) was made of wood chips with access to tunnel shelter, nesting material, and a wooden stick. For mice, cages were lined with wood shavings without enrichment material in the cages. Female and male animals were allocated in different rooms to avoid interference in the behavioral results.

The Ethics Committee approved the experimental protocols for the use of animals from the School of Pharmaceutical Sciences of Ribeirão Preto-USP (protocol number 17.1.537.60.6) and the Danish Animal Experiments Inspectorate (protocol number 2016150201-001105). The experimental procedures were conducted following the National Council for Control of Animal Experimentation (CONCEA, Brasília, DF, Brazil) and European Community Council Directive 2010/63/EU. All behavioral experiments were conducted between 9:00 a.m. and 1:00 p.m.

\subsection{Drugs}

Synthetic cannabidiol (CBD; Prati-Donaduzzi, Toledo, PR, Brazil; doses: 3, 10, and $30 \mathrm{mg} / 10 \mathrm{~mL} / \mathrm{kg}$ intraperitoneal (i.p.)) stored at $4{ }^{\circ} \mathrm{C}$ and protected from light, diluted with sterile saline and $2 \%$ polysorbate 80 (Tween ${ }^{\circledR} 80$; Synth, Diadema, SP, Brazil) for mice [24-26] or synthetic CBD (THC-Pharma, Frankfurt, HE, Germany; doses: 10, 30, and $60 \mathrm{mg} / \mathrm{kg} / 2 \mathrm{~mL}$ i.p.) diluted with sterile saline and $3 \%$ polysorbate 80 (Tween ${ }^{\circledR} 80$; SigmaAldrich, St. Louise, MO, USA) for systemic administration in FSL rats [24]. S-ketamine hydrochloride (Pfizer Ltd.a, Ballerup, Denmark; doses: 10, 15, and $20 \mathrm{mg} / \mathrm{kg} / 2 \mathrm{~mL}$ i.p.) stored at $4{ }^{\circ} \mathrm{C}$ was dissolved in sterile saline $[24,105]$ and imipramine hydrochloride (IMIP; Abcam, Waltham, MA, USA; dose: $20 \mathrm{mg} / \mathrm{kg} / 10 \mathrm{~mL}$ ), stored at $4{ }^{\circ} \mathrm{C}$ and diluted in sterile saline [106]. The vehicle (VEH) group received CBD vehicle injections. All drugs were freshly prepared before the experiment. The animals received the treatment randomly by writing down the treatment in pieces of paper, folding them, then drawing one by one for each animal [107].

\subsection{Methods and Experimental Design}

\subsubsection{Mice}

Experiments 1 and 2-CBD Effects in Male and Female Mice Exposed to EPM and TST

The elevated plus maze (EPM) and the tail suspension test (TST) were conducted to investigate the anxiolytic and antidepressant-related behaviors in mice. The EPM was performed as previously described $[27,108]$. The apparatus was a plus-shaped maze made of wood and consisted of 2 equals enclosed arms (EA; $30 \mathrm{~cm} \times 6 \mathrm{~cm}$; surrounded by walls 
$15 \mathrm{~cm}$ high) disposed perpendicularly to a 2 equals open arms (OA; $30 \mathrm{~cm} \times 6 \mathrm{~cm})$. The animals were placed in the center of the equipment facing one EA and freely exploring the maze for $5 \mathrm{~min}$. The OA entries, time, and percentage of time spent in the OA were analyzed. Also, EA entries were assessed as an exploratory behavior, as described in $[103,108]$.

In the TST, the animal was suspended $60 \mathrm{~cm}$ above the floor with the adhesive tape placed $1 \mathrm{~cm}$ at the tip of the tail on the experimentation table for $6 \min [47,109]$. Moreover, a plastic cylinder tubing ( $40 \mathrm{~mm}$ length; $16 \mathrm{~mm}$ diameter) was placed around the animal tail to prevent tail-climbing behavior, as described previously [110].

Thirty minutes after the habituation period in the experimental room, the mice received the intraperitoneal injection with VEH, IMIP, or CBD $(3,10$, and $30 \mathrm{mg} / \mathrm{kg})$. Thirty minutes later, the animals were exposed to the EPM ( $5 \mathrm{~min}$ ) and TST (6 min). To avoid interference in the behavioral response in the tests, the experiment carried out with females was performed independently and on different days from male animals. The female reproductive cycle status was not taken into account [111].

Independent experiments were carried out for Swiss and C57BL/ 6 mice for each sex (a total of four independent experiments).

\subsubsection{Flinders Sensitive Line (FSL) Rats}

Experiment 3-CBD Effect 1 and $2 \mathrm{~h}$ before OFT/FST in Male FSL Rats

To assess whether CBD produced an antidepressant-like effect 1 or $2 \mathrm{~h}$ after the injection, the rats received an i.p. injection with $\mathrm{VEH}$, ketamine $(15 \mathrm{mg} / \mathrm{kg})$, or CBD $(10,30$, and $60 \mathrm{mg} / \mathrm{kg}$ ). After $50 \mathrm{~min}$ or $1 \mathrm{~h} 50 \mathrm{~min}$, the animals were exposed to the OFT ( $5 \mathrm{~min}$ ) and, immediately after, they were submitted to the FST ( $5 \mathrm{~min}$ ). The FST was performed, as previously described $[24,112]$. The FSL and FRL rats were exposed to a $10 \mathrm{~min}$ test in a Perspex cylinder (height $60 \mathrm{~cm}$, diameter $24 \mathrm{~cm}$ ) filled with tap water at $24 \pm 1^{\circ} \mathrm{C}$, up to $40 \mathrm{~cm}$ height, and the immobility time was measured in the first $5 \mathrm{~min}$ [24].

To analyze the unspecific change in the locomotor activity produced by the drug treatment, an open field test (OFT) was performed, as previously described [113]. Immediately before the test in the FST (see below), the rats were submitted individually to an open field square $(100 \mathrm{~cm} \times 100 \mathrm{~cm})$ for $5 \mathrm{~min}$. The light intensity was 40 lux at the center of the arena. The total distance traveled (meter; $\mathrm{m}$ ) was subsequently analyzed using EthoVision ${ }^{\circledR}$ XT14 (Noldus Information Technology, Wageningen, The Netherlands).

In addition, the FSL and FRL rats were handled for 3-5 min during three consecutive days before the experiment to habituate the animals to the experimenter and minimize stress caused by manipulation.

Experiment 4-Dose-Response Curves with Ketamine in Female FSL Rats Exposed to OFT/FST

A dose-response curve with ketamine was conducted to determine the effective dose that produced antidepressant-like effects in female FSL rats. For this purpose, $1 \mathrm{~h}$ after the habituation in the experimental room, the female FRL rats received systemic treatment with VEH (sterile saline), and female FSL rats were treated with VEH or ketamine (10, 15, and $20 \mathrm{mg} / \mathrm{kg}$ i.p.). Fifty minutes later, the rats were submitted to OFT (5 $\mathrm{min}$ ) and FST (10 $\mathrm{min}$ ), as previously described. The rat reproductive cycle status was not considered, as it was earlier shown not to affect immobility $[100,114]$.

\section{Experiment 5-CBD Effect 1 and $2 \mathrm{~h}$ before OFT/FST in Female FSL Rats}

A similar design described in Experiment 3 was used for females, except that Sketamine was $20 \mathrm{mg} / \mathrm{kg}$. To avoid interference in the behavioral response in the tests, the experiment carried out with females was conducted independently and on different days than the males. The rat reproductive cycle status was not considered [100,114]. 


\subsection{Data Analysis}

A three-way analysis of variance (ANOVA) with treatment, sex, strain or time (with FSL rats) as independent factors was performed to examine the behavioral data. To measure significant effects of the strain and in the interaction (treatment vs. strain), we performed an independent two-way ANOVA to evaluate the treatment and sex effect in each mice strain, Swiss and C57BL/6. In sequence, to measure significant effect on the treatment and interaction (sex vs. treatment), we performed a one-way ANOVA on each sex to compare the treatment effect on immobility. However, for FSL rats, to compare significant effects of the interaction (treatment vs. sex vs. time), we performed the following tests: (i) Student's $t$-test to compare the results between the rat strain, FRL and FSL vehicle-treated groups and (ii) one-way ANOVA test followed by Dunnett post hoc test to compare differences between FSL-VEH and FSL-ketamine or FSL-CBD and mice treated groups (VEH, IMIP, and CBD). When the variances between the groups were not homogenous, Mann-Whitney (for comparisons between FSL and FRL vehicle-treated groups) or Kruskal-Wallis followed by Dunn's post hoc test (to compare between FSL treated with VEH, ketamine, and CBD and treated mice) was applied. Significant outliers were removed from the statistical analysis through GraphPad' Outlier calculator (online version, 2021; GraphPad Software Inc., San Diego, CA, USA). The outliers were the following: male and female FSL rats: 1 rat/sex; female C57BL/ 6 and male Swiss mice: 5 animals/strain; male C57BL/ 6 and female Swiss mice: 3 animals/strain. We calculated and reported the effect size from TST and FST using G*Power (version 3.1.9.6, Heinrich Heine Universität, Düsseldorf, NRW, Germany) [115]. Results in the graphs are expressed as the mean \pm standard error of the mean (SEM). A significant difference between groups was considered when $p \leq 0.05$. The $p$-value between 0.05 and 0.1 was considered a statistical trend [116]. Statistical analyses were performed using GraphPad Prism 8.0 (GraphPad Software Inc., San Diego, CA, USA) and SPSS software (version 20.0), and the graphs were created using GraphPad Prism 8.0 (GraphPad Software Inc., San Diego, CA, USA). The raw data are published on FigShare [117].

\section{Conclusions}

In conclusion, our findings point out that sex, animal strain, species, and injection time may affect the behavioral response induced by CBD in rodents submitted to animal models of depression. CBD produced an antidepressant-like effect only in male Swiss mice and no effect in female Swiss mice or C57BL/ 6 mice (both sexes) was observed. Notably, in female FSL rats, CBD produced an antidepressant effect $2 \mathrm{~h}$ post injection and tended to induce a depressive-like effect at $1 \mathrm{~h}$. In male FSL, CBD tended to cause an antidepressant at $1 \mathrm{~h}$ but not at $2 \mathrm{~h}$. Therefore, these findings indicate that it is necessary to consider the sex, animal strain and species, compound chemistry, exposure, and behavioral test when evaluating novel drugs for depression.

Author Contributions: Conceptualization, G.P.S., S.R.L.J. and G.W.; methodology, G.P.S., M.C.G. and A.E.; formal analysis, G.P.S. and F.S.G.; investigation, G.P.S., M.C.G. and A.E.; writing-original draft preparation, G.P.S.; writing—review and editing, M.C.G., A.E., S.R.L.J., G.W. and F.S.G.; supervision, S.R.L.J. and G.W.; project administration, S.R.L.J. and G.W.; funding acquisition, S.R.L.J. and G.W. All authors have read and agreed to the published version of the manuscript.

Funding: G.P.S. acknowledges grant support from the São Paulo Research Foundation (FAPESP; Grant numbers 2017/26815-1 and 2018/12119-6) and National Council for Scientific and Technological Development: (CNPq; Grant number 141585/2016-1). M.C.G. is thankful to the CNPq for the fellowship for PIBIC. G.W. is thankful to Independent Research Fund Denmark (grant 8020-00310B), Aarhus University Research Foundation, Denmark (AU-IDEAS initiative (eMOOD)), and EU Horizon 2020 (ExEDE). S.R.L.J. has received funding from the AIAS-COFUND II fellowship program supported by the Marie Skłodowska-Curie actions under the European Union's Horizon 2020 (Grant agreement number 754513) Aarhus University Research Foundation. S.R.L.J. is thankful to the CNPq for fellowships for productivity in research (304780/2018-9). 
Institutional Review Board Statement: The study was conducted following the National Council for Control of Animal Experimentation (CONCEA, Brazil) and European Community Council Directive 2010/63/EU and approved by the Local Ethics Committee for the Use of Animals from the School of Pharmaceutical Sciences of Ribeirão Preto-USP (Protocol number 17.1.537.60.6 and approval 10 July 2019) and the Danish Animal Experiments Inspectorate (Protocol number 2016-150201-001105 and approval 23 December 2016).

Informed Consent Statement: Not applicaple.

Data Availability Statement: The data presented in this study are openly available in FigShare at [https://doi.org/10.6084/m9.figshare.16583408.v1; https://doi.org/10.6084/m9.figshare.16583402 .v1; https:/ / doi.org/10.6084/m9.figshare.16583408.v1; https:/ / doi.org/10.6084/m9.figshare.1658 3417.v1; https:/ / doi.org/10.6084/m9.figshare.16589687.v1; https:/ /doi.org/10.6084/m9.figshare. 16589696.v1], reference number [117].

Acknowledgments: The authors acknowledge Miriam Contin Melo, Flávia Fiacadori Salata and Per Fuglsang Mikkelsen for their helpful technical assistance.

Conflicts of Interest: The authors declare no conflict of interest.

\section{References}

1. APA. Diagnostic and Statictical Manual of Mental Disorders; American Psychiatric Association: New York, NY, USA, 2013; ISBN 9780890425541.

2. WHO. Depression and Other Common Mental Disorders: Global Health Estimates; WHO: Geneva, Switzerland, 2017.

3. WHO. Investing in Treatment for Depression and Anxiety Leads to Fourfold Return; WHO: Geneva, Switzerland, 2017; pp. 1-3.

4. Hasin, D.S.; Sarvet, A.L.; Meyers, J.L.; Saha, T.D.; Ruan, W.J.; Stohl, M.; Grant, B.F. Epidemiology of adult DSM-5 major depressive disorder and its specifiers in the United States. JAMA Psychiatry 2018, 75, 336-346. [CrossRef]

5. Kessler, R.; Bromet, E. The epidemiology of depression across cultures. Annu. Rev. Public Health 2013, 34, 119-138. [CrossRef] [PubMed]

6. Chisholm, D.; Sweeny, K.; Sheehan, P.; Rasmussen, B.; Smit, F.; Cuijpers, P.; Saxena, S. Scaling-up treatment of depression and anxiety: A global return on investment analysis. Lancet Psychiatry 2016, 3, 415-424. [CrossRef]

7. Olesen, J.; Gustavsson, A.; Svensson, M.; Wittchen, H.U.; Jönsson, B. The economic cost of brain disorders in Europe. Eur. J. Neurol. 2012, 19, 155-162. [CrossRef] [PubMed]

8. Beery, A.K.; Zucker, I. Sex bias in neuroscience and biomedical research. Neurosci. Biobehav. Rev. 2011, 35, 565-572. [CrossRef] [PubMed]

9. Herzog, D.P.; Wegener, G.; Lieb, K.; Müller, M.B.; Treccani, G. Decoding the mechanism of action of rapid-acting antidepressant treatment strategies: Does gender matter? Int. J. Mol. Sci. 2019, 20, 949. [CrossRef]

10. Will, T.R.; Proaño, S.B.; Thomas, A.M.; Kunz, L.M.; Thompson, K.C.; Ginnari, L.A.; Jones, C.H.; Lucas, S.C.; Reavis, E.M.; Dorris, D.M.; et al. Problems and progress regarding sex bias and omission in neuroscience research. eNeuro 2017, 4, 1-10. [CrossRef]

11. Zakiniaeiz, Y.; Cosgrove, K.P.; Potenza, M.N.; Mazure, C.M. Balance of the sexes: Addressing sex differences in preclinical research. Yale J. Biol. Med. 2016, 89, 255-259.

12. Karp, N.A.; Reavey, N. Sex bias in preclinical research and an exploration of how to change the status quo. Br. J. Pharmacol. 2019, 176, 4107-4118. [CrossRef] [PubMed]

13. Lee, S.K. Sex as an important biological variable in biomedical research. BMB Rep. 2018, 51, 167-173. [CrossRef]

14. Adams, R.; Hunt, M.; Clark, J.H. Structure of Cannabidiol, a Product Isolated from the Marihuana Extract of Minnesota Wild Hemp. I. J. Am. Chem. Soc. 1940, 62, 196-200. [CrossRef]

15. Perez-Reyes, M.; Timmons, M.C.; Davis, K.H.; Wall, E.M. A comparison of the pharmacological activity in man of intravenously administered $\Delta$ 9- Tetrahydrocannabinol, cannabinol, and cannabidiol. Experientia 1973, 29, 1368-1369. [CrossRef] [PubMed]

16. Silote, G.P.; Sartim, A.; Sales, A.; Eskelund, A.; Guimarães, F.S. Emerging evidence for the antidepressant effect of cannabidiol and the underlying molecular mechanisms. J. Chem. Neuroanat. 2019, 98, 104-116. [CrossRef]

17. Vitale, R.M.; Iannotti, F.A.; Amodeo, P. The (Poly)pharmacology of cannabidiol in neurological and neuropsychiatric disorders: Molecular mechanisms and targets. Int. J. Mol. Sci. 2021, 22, 4876. [CrossRef] [PubMed]

18. Pisanti, S.; Malfitano, A.M.; Ciaglia, E.; Lamberti, A.; Ranieri, R.; Cuomo, G.; Abate, M.; Faggiana, G.; Proto, M.C.; Fiore, D.; et al. Cannabidiol: State of the art and new challenges for therapeutic applications. Pharmacol. Ther. 2017, 175, 133-150. [CrossRef] [PubMed]

19. Blessing, E.M.; Steenkamp, M.M.; Manzanares, J.; Marmar, C.R. Cannabidiol as a Potential Treatment for Anxiety Disorders. Neurotherapeutics 2015, 12, 825-836. [CrossRef]

20. Bonaccorso, S.; Ricciardi, A.; Zangani, C.; Chiappini, S.; Schifano, F. Cannabidiol (CBD) use in psychiatric disorders: A systematic review. Neurotoxicology 2019, 74, 282-298. [CrossRef] 
21. Zuardi, A.W.; Rodrigues, N.P.; Silva, A.L.; Bernardo, S.A.; Hallak, J.E.C.; Guimarães, F.S.; Crippa, J.A.S. Inverted U-shaped dose-response curve of the anxiolytic effect of cannabidiol during public speaking in real life. Front. Pharmacol. 2017, 8, 259. [CrossRef]

22. El-Alfy, A.T.; Ivey, K.; Robinson, K.; Ahmed, S.; Radwan, M.; Slade, D.; Khan, I.; ElSohly, M.; Ross, S. Antidepressant-like effect of delta9-tetrahydrocannabinol and other cannabinoids isolated from Cannabis sativa L. Pharmacol. Biochem. Behav. 2010, 95, 434-442. [CrossRef]

23. Réus, G.Z.; Stringari, R.B.; Ribeiro, K.F.; Luft, T.; Abelaira, H.M.; Fries, G.R.; Aguiar, B.W.; Kapczinski, F.; Hallak, J.E.; Zuardi, A.W.; et al. Administration of cannabidiol and imipramine induces antidepressant-like effects in the forced swimming test and increases brain-derived neurotrophic factor levels in the rat amygdala. Acta Neuropsychiatr. 2011, 23, 241-248. [CrossRef]

24. Sales, A.J.; Fogaça, M.V.; Sartim, A.G.; Pereira, V.S.; Wegener, G.; Guimarães, F.S.; Joca, S.R.L. Cannabidiol Induces Rapid and Sustained Antidepressant-Like Effects Through Increased BDNF Signaling and Synaptogenesis in the Prefrontal Cortex. Mol. Neurobiol. 2018, 56, 1070-1081. [CrossRef]

25. Sales, A.J.; Crestani, C.C.; Guimarães, F.S.; Joca, S.R.L. Antidepressant-like effect induced by Cannabidiol is dependent on brain serotonin levels. Prog. Neuro-Psychopharmacol. Biol. Psychiatry 2018, 86, 255-261. [CrossRef] [PubMed]

26. Zanelati, T.V.; Biojone, C.; Moreira, F.A.; Guimaraes, F.S.; Joca, S.R.L. Antidepressant-like effects of cannabidiol in mice: Possible involvement of 5-HT 1A receptors. Br. J. Pharmacol. 2010, 159, 122-128. [CrossRef] [PubMed]

27. Schiavon, A.P.; Bonato, J.M.; Milani, H.; Guimarães, F.S.; Weffort de Oliveira, R.M. Influence of single and repeated cannabidiol administration on emotional behavior and markers of cell proliferation and neurogenesis in non-stressed mice. Prog. NeuroPsychopharmacol. Biol. Psychiatry 2016, 64, 27-34. [CrossRef] [PubMed]

28. Linge, R.; Jiménez-Sánchez, L.; Campa, L.; Pilar-Cuéllar, F.; Vidal, R.; Pazos, A.; Adell, A.; Díaz, Á. Cannabidiol induces rapid-acting antidepressant-like effects and enhances cortical 5-HT/glutamate neurotransmission: Role of 5-HT1A receptors. Neuropharmacology 2016, 103, 16-26. [CrossRef]

29. Xu, C.; Chang, T.; Du, Y.; Yu, C.; Tan, X.; Li, X. Pharmacokinetics of oral and intravenous cannabidiol and its antidepressant-like e ff ects in chronic mild stress mouse model. Environ. Toxicol. Pharmacol. 2019, 70, 103202. [CrossRef]

30. Gáll, Z.; Farkas, S.; Albert, Á.; Ferencz, E.; Vancea, S.; Urkon, M.; Kolcsár, M. Effects of chronic cannabidiol treatment in the rat chronic unpredictable mild stress model of depression. Biomolecules 2020, 10, 801. [CrossRef]

31. Shoval, G.; Shbiro, L.; Hershkovitz, L.; Hazut, N.; Zalsman, G.; Mechoulam, R.; Weller, A. Prohedonic effect of cannabidiol in a rat model of depression. Neuropsychobiology 2016, 73, 123-129. [CrossRef]

32. Shbiro, L.; Hen-shoval, D.; Hazut, N.; Rapps, K.; Dar, S.; Zalsman, G.; Mechoulam, R.; Weller, A.; Shoval, G. Effects of cannabidiol in males and females in two different rat models of depression. Physiol. Behav. 2019, 201, 59-63. [CrossRef]

33. Bambico, F.R.; Katz, N.; Debonnel, G.; Gobbi, G. Cannabinoids elicit antidepressant-like behavior and activate serotonergic neurons through the medial prefrontal cortex. J. Neurosci. 2007, 27, 11700-11711. [CrossRef]

34. Kirkedal, C.; Wegener, G.; Moreira, F.; Joca, S.R.L.; Liebenberg, N. A dual inhibitor of FAAH and TRPV1 channels shows dose-dependent effect on depression-like behaviour in rats. Acta Neuropsychiatr. 2017, 29, 324-329. [CrossRef] [PubMed]

35. An, X.; Zou, J.; Wu, R.; Yang, Y.; Tai, F. Strain and Sex Differences in Anxiety-Like and Social Behaviors in C57BL/6J and BALB/cJ Mice. Exp. Anim. 2011, 60, 111-123. [CrossRef] [PubMed]

36. Bai, F.; Li, X.; Clay, M.; Lindstrom, T.; Skolnick, P. Intra- and interstrain differences in models of "behavioral despair". Pharmacol. Biochem. Behav. 2001, 70, 187-192. [CrossRef]

37. David, D.J.P.; Renard, C.E.; Jolliet, P.; Hascoët, M.; Bourin, M. Antidepressant-like effects in various mice strains in the forced swimming test. Psychopharmacology 2003, 166, 373-382. [CrossRef]

38. Liu, X.; Gershenfeld, H.K. Genetic differences in the tail-suspension test and its relationship to imipramine response among 11 inbred strains of mice. Biol. Psychiatry 2001, 49, 575-581. [CrossRef]

39. Marchette, R.C.N.; Bicca, M.A.; Santos, E.C.D.S.; de Lima, T.C.M. Distinctive stress sensitivity and anxiety-like behavior in female mice: Strain differences matter. Neurobiol. Stress 2018, 9, 55-63. [CrossRef] [PubMed]

40. Ripoll, N.; Joseph, D.; David, P.; Dailly, E.; Hascoët, M.; Bourin, M. Antidepressant-like effects in various mice strains in the tail suspension test. Behav. Brain Res. 2003, 143, 193-200. [CrossRef]

41. Võikar, V.; Kõks, S.; Vasar, E.; Rauvala, H. Strain and gender differences in the behavior of mouse lines commonly used in transgenic studies. Physiol. Behav. 2001, 72, 271-281. [CrossRef]

42. Porsolt, R.D.; Bertin, A.; Jalfre, M. “Behavioural despair” in rats and mice: Strain differences and the effects of imipramine. Eur. J. Pharmacol. 1978, 51, 291-294. [CrossRef]

43. Liu, X.; Gershenfeld, H.K. An exploratory factor analysis of the Tail Suspension Test in 12 inbred strains of mice and an F2 intercross. Brain Res. Bull. 2003, 60, 223-231. [CrossRef]

44. Sales, A.J.; Guimarães, F.S.; Joca, S.R.L. CBD modulates DNA methylation in the prefrontal cortex and hippocampus of mice exposed to forced swim. Behav. Brain Res. 2020, 388, 112627. [CrossRef]

45. Campos, A.C.; Ortega, Z.; Palazuelos, J.; Fogaca, M.V.; Aguiar, D.C.; Diaz-Alonso, J.; Ortega-Gutierrez, S.; Vazquez-Villa, H.; Moreira, F.A.; Guzmán, M.; et al. The anxiolytic effect of cannabidiol on chronically stressed mice depends on hippocampal neurogenesis: Involvement of the endocannabinoid system. Int. J. Neuropsychopharmacol. 2013, 16, 1407-1419. [CrossRef] [PubMed] 
46. Fogaça, M.V.; Campos, A.C.; Coelho, L.D.; Duman, R.S.; Guimarães, F.S. The anxiolytic effects of cannabidiol in chronically stressed mice are mediated by the endocannabinoid system: Role of neurogenesis and dendritic remodeling. Neuropharmacology 2018, 135, 22-33. [CrossRef]

47. Cryan, J.F.; Mombereau, C.; Vassout, A. The tail suspension test as a model for assessing antidepressant activity: Review of pharmacological and genetic studies in mice. Neurosci. Biobehav. Rev. 2005, 29, 571-625. [CrossRef]

48. Shoji, H.; Takao, K.; Hattori, S.; Miyakawa, T. Age-related changes in behavior in C57BL/6J mice from young adulthood to middle age. Mol. Brain 2016, 9, 11. [CrossRef]

49. Mason, S.S.; Baker, K.B.; Davis, K.W.; Pogorelov, V.M.; Malbari, M.M.; Ritter, R.; Wray, S.P.; Gerhardt, B.; Lanthorn, T.H.; Savelieva, K.V. Differential sensitivity to SSRI and tricyclic antidepressants in juvenile and adult mice of three strains. Eur. J. Pharmacol. 2009, 602, 306-315. [CrossRef]

50. Mitchell, N.C.; Koek, W.; Daws, L.C.; Antonio, S.; Antonio, S.; Antonio, S. Antidepressant-like effects and basal immobility depend on age and serotonin transporter genotype. Genes Brain Behav. 2015, 14, 543-549. [CrossRef]

51. Wang, S.; Huang, G.; Yan, J.; Li, C.; Feng, J.; Chen, Q.; Zheng, X.; Li, H.; Li, J.; Wang, L.; et al. Influence of aging on chronic unpredictable mild stress-induced depression-like behavior in male C57BL/6J mice. Behav. Brain Res. 2021, 414, 113486. [CrossRef]

52. Deiana, S.; Watanabe, A.; Yamasaki, Y.; Amada, N.; Arthur, M.; Fleming, S.; Woodcock, H.; Dorward, P.; Pigliacampo, B.; Close, S.; et al. Plasma and brain pharmacokinetic profile of cannabidiol (CBD), cannabidivarine (CBDV), $\triangle$ 9-tetrahydrocannabivarin (THCV) and cannabigerol (CBG) in rats and mice following oral and intraperitoneal administration and CBD action on obsessivecompulsive behav. Psychopharmacology 2012, 219, 859-873. [CrossRef] [PubMed]

53. Kasten, C.R.; Zhang, Y.; Boehm, S.L. Acute cannabinoids produce robust anxiety-like and locomotor effects in mice, but long-term consequences are age- And sex-dependent. Front. Behav. Neurosci. 2019, 13, 32. [CrossRef] [PubMed]

54. Long, L.E.; Chesworth, R.; Huang, X.F.; McGregor, I.S.; Arnold, J.C.; Karl, T. A behavioural comparison of acute and chronic 9tetrahydrocannabinol and cannabidiol in C57BL/6JArc mice. Int. J. Neuropsychopharmacol. 2010, 13, 861-876. [CrossRef] [PubMed]

55. Lucki, I.; Dalvi, A.; Mayorga, A.J. Sensitivity to the effects of pharmacologically selective antidepressants in different strains of mice. Psychopharmacology 2001, 155, 315-322. [CrossRef]

56. Jin, Z.; Chen, X.; Ran, Y.; Li, X.; Xiong, J.; Zheng, Y. Mouse strain differences in SSRI sensitivity correlate with serotonin transporter binding and function. Sci. Rep. 2017, 7, 8631. [CrossRef] [PubMed]

57. Torrisi, S.A.; Lavanco, G.; Maurel, O.M.; Gulisano, W.; Laudani, S.; Geraci, F.; Grasso, M.; Barbagallo, C.; Caraci, F.; Bucolo, C.; et al. A novel arousal-based individual screening reveals susceptibility and resilience to PTSD-like phenotypes in mice. Neurobiol. Stress 2021, 14, 100286. [CrossRef]

58. Pascual Cuadrado, D.; Todorov, H.; Lerner, R.; Islami, L.; Bindila, L.; Gerber, S.; Lutz, B. Long-term molecular differences between resilient and susceptible mice after a single traumatic exposure. Br. J. Pharmacol. 2021. [CrossRef]

59. Fernández-Guasti, A.; Olivares-Nazario, M.; Reyes, R.; Martínez-Mota, L. Sex and age differences in the antidepressant-like effect of fluoxetine in the forced swim test. Pharmacol. Biochem. Behav. 2017, 152, 81-89. [CrossRef]

60. Franceschelli, A.; Sens, J.; Herchick, S.; Thelen, C.; Pitychoutis, P.M. Sex differences in the rapid and the sustained antidepressantlike effects of ketamine in stress-nai"ve and "'depressed"' mice exposed to chronic mild stress. Neuroscience 2015, 290, 49-60. [CrossRef]

61. Gómez, M.L.; Martínez-Mota, L.; Estrada-Camarena, E.; Fernández-Guasti, A. Influence of the brain sexual differentiation process on despair and antidepressant-like effect of fluoxetine in the rat forced swim test. Neuroscience 2014, 261, 11-22. [CrossRef] [PubMed]

62. Simpson, J.; Ryan, C.; Curley, A.; Mulcaire, J.; Kelly, J.P. Sex differences in baseline and drug-induced behavioural responses in classical behavioural tests. Prog. Neuropsychopharmacol. Biol. Psychiatry 2012, 37, 227-236. [CrossRef]

63. Wright, K.N.; Kabbaj, M. Sex differences in sub-anesthetic ketamine's antidepressant effects and abuse liability. Curr. Opin. Behav. Sci. 2018, 23, 36-41. [CrossRef]

64. Melo, A.; Kokras, N.; Dalla, C.; Ferreira, C.; Ventura-Silva, A.P.; Sousa, N.; Pego, J.M. The positive effect on ketamine as a priming adjuvant in antidepressant treatment. Transl. Psychiatry 2015, 5, e573. [CrossRef]

65. Carrier, N.; Kabbaj, M. Sex differences in the antidepressant-like effects of ketamine. Neuropharmacology 2013, 70, 27-34. [CrossRef]

66. Onaivi, E.S.; Green, M.R.; Martin, B.R. Pharmacological Characterization of Cannabinoids in the Elevated Plus Maze. J. Pharmacol. Exp. Ther. 1990, 253, 1002-1009. [PubMed]

67. Liu, J.; Scott, B.W.; Burnham, W.M. Effects of cannabidiol and $\Delta 9$-tetrahydrocannabinol in the elevated plus maze in mice. Behav Pharmacol. 2021. [CrossRef] [PubMed]

68. Kaufman, J.; Charney, D. Comorbidity of mood and anxiety disorders. Depress. Anxiety 2000, 12, 69-76. [CrossRef]

69. Otte, C.; Gold, S.M.; Penninx, B.W.; Pariante, C.M.; Etkin, A.; Fava, M.; Mohr, D.C.; Schatzberg, A.F. Major depressive disorder. Nat. Rev. Dis. Prim. 2016, 2, 16065. [CrossRef]

70. de Morais, H.; Chaves, Y.C.; Waltrick, A.P.F.; Jesus, C.H.A.; Genaro, K.; Crippa, J.A.; da Cunha, J.M.; Zanoveli, J.M. Sub-chronic treatment with cannabidiol but not with URB597 induced a mild antidepressant-like effect in diabetic rats. Neurosci. Lett. 2018, 682, 62-68. [CrossRef] [PubMed]

71. Mechoulam, R.; Shvo, Y. The structure of cannabidiol. Tetrahedrom 1963, 19, 2073-2078. [CrossRef]

72. Huestis, M.A. Human cannabinoid pharmacokinetics. Chem. Biodivers. 2007, 4, 1770-1804. [CrossRef] 
73. Turner, P.V.; Brabb, T.; Pekow, C.; Vasbinder, M.A. Administration of substances to laboratory animals: Routes of administration and factors to consider. J. Am. Assoc. Lab. Anim. Sci. 2011, 50, 600-613.

74. Al Shoyaib, A.; Archie, S.R.; Karamyan, V.T. Intraperitoneal Route of Drug Administration: Should it Be Used in Experimental Animal Studies? Pharm. Res. 2020, 37, 12. [CrossRef]

75. Harvey, D.J. Absorption, Distribution, and Biotransformation of the Cannabinoids. Marihuana Med. 1999, 91-103. [CrossRef]

76. Grotenhermen, F. Pharmacokinetics and pharmacodynamics of cannabinoids. Clin. Pharmacokinet. 2003, 42, 327-360. [CrossRef] [PubMed]

77. Lucas, C.J.; Galettis, P.; Schneider, J. The pharmacokinetics and the pharmacodynamics of cannabinoids. Br. J. Clin. Pharmacol. 2018, 84, 2477-2482. [CrossRef] [PubMed]

78. McGilveray, I.J. Pharmacokinetics of cannabinoids. Pain Res. Manag. 2005, 10, 15A-22A. [CrossRef]

79. Harvey, D.J.; Samara, E.; Mechoulam, R. Comparative metabolism of cannabidiol in dog, rat and man. Pharmacol. Biochem. Behav. 1991, 40, 523-532. [CrossRef]

80. Harvey, D.J.; Brown, N.K. Comparative in vitro metabolism of the cannabinoids. Pharmacol. Biochem. Behav. 1991, 40, 533-540. [CrossRef]

81. Samara, E.; Bialer, M.; Harvey, D.J. Metabolism of cannabidiol by the rat. Eur. J. Drug Metab. Pharmacokinet. 1991, 16, 305-313. [CrossRef]

82. Narimatsu, S.; Watanabe, K.; Yamamoto, I.; Yoshimura, H. Sex difference in the oxidative metabolism of Delta9tetrahydrocannabinol in the rat. Biochem. Pharmacol. 1991, 41, 1187-1194. [CrossRef]

83. Wiley, J.L.; Burston, J.J. Sex differences in 89 -tetrahydrocannabinol metabolism and in vivo pharmacology following acute and repeated dosing in adolescent rats. Neurosci. Lett. 2014, 576, 51-55. [CrossRef]

84. Bradshaw, H.B.; Rimmerman, N.; Krey, J.F.; Walker, J.M. Sex and hormonal cycle differences in rat brain levels of pain-related cannabimimetic lipid mediators. Am. J. Physiol. Regul. Integr. Comp. Physiol. 2006, 291, 349-358. [CrossRef]

85. Carlsson, M.; Carlsson, A. A regional study of sex differences in rat brain serotonin. Prog. Neuropsychopharmacol. Biol. Psychiatry 1988, 12, 53-61. [CrossRef]

86. de Fonseca, F.R.; Cebeira, M.; Ramos, J.A.; Martín, M.; Fernández-Ruiz, J.J. Cannabinoid receptors in rat brain areas: Sexual differences, fluctuations during estrous cycle and changes after gonadectomy and sex steroid replacement. Life Sci. 1994, 54, 159-170. [CrossRef]

87. Riebe, C.J.N.; Hill, M.N.; Lee, T.T.Y.; Hillard, C.J.; Gorzalka, B.B. Estrogenic regulation of limbic cannabinoid receptor binding. Psychoneuroendocrinology 2010, 35, 1265-1269. [CrossRef] [PubMed]

88. Fischette, C.T.; Biegon, A.; McEwen, B.S. Sex differences in serotonin 1 receptor binding in rat brain. Science 1983, 222, 333-335. [CrossRef]

89. Zhang, L.; Ma, W.; Barker, J.L.; Rubinow, D.R. Sex differences in expression of serotonin receptors (subtypes 1A and 2A) in rat brain: A possible role of testosterone. Neuroscience 1999, 94, 251-259. [CrossRef]

90. Carrier, N.; Wang, X.; Sun, L.; Lu, X.Y. Sex-specific and estrous cycle-dependent antidepressant-like effects and hippocampal Akt signaling of leptin. Endocrinology 2015, 156, 3695-3705. [CrossRef] [PubMed]

91. Chou, D.; Peng, H.Y.; Lin, T.B.; Lai, C.Y.; Hsieh, M.C.; Wen, Y.C.; Lee, A.S.; Wang, H.H.; Yang, P.S.; Chen, G.D.; et al. (2R,6R)hydroxynorketamine rescues chronic stress-induced depression-like behavior through its actions in the midbrain periaqueductal gray. Neuropharmacology 2018, 139, 1-12. [CrossRef]

92. Rincón-Cortés, M.; Grace, A.A. Sex-dependent effects of stress on immobility behavior and VTA dopamine neuron activity: Modulation by ketamine. Int. J. Neuropsychopharmacol. 2017, 20, 823-832. [CrossRef]

93. Sarkar, A.; Kabbaj, M. Sex differences in effects of ketamine on behavior, spine density and synaptic proteins in socially isolated rats. Biol. Psychiatry 2017, 80, 448-456. [CrossRef]

94. Tizabi, Y.; Bhatti, B.H.; Manaye, K.F.; Das, J.R.; Akinfiresoye, L. Antidepressant-like effects of low ketamine dose is associated with increased hippocampal AMPA/NMDA receptor density ratio in female Wistar-Kyoto rats. Neuroscience 2012, 213, 72-80. [CrossRef] [PubMed]

95. Ardalan, M.; Elfving, B.; Rafati, A.H.; Mansouri, M.; Zarate, C.A.; Mathe, A.A.; Wegener, G. Rapid effects of S-ketamine on the morphology of hippocampal astrocytes and BDNF serum levels in a sex-dependent manner. Eur. Neuropsychopharmacol. 2020, 1-10. [CrossRef] [PubMed]

96. Consoli, D.; Fedotova, J.; Micale, V.; Sapronov, N.S.; Drago, F. Stressors affect the response of male and female rats to clomipramine in a model of behavioral despair (forced swim test). Eur. J. Pharmacol. 2005, 520, 100-107. [CrossRef] [PubMed]

97. D'Souza, D.; Sadananda, M. Estrous cycle phase-dependent changes in anxiety-and depression-like profiles in the late adolescent Wistar-Kyoto rat. Ann. Neurosci. 2017, 24, 136-145. [CrossRef] [PubMed]

98. Jaric, I.; Rocks, D.; Cham, H.; Herchek, A.; Kundakovic, M. Sex and estrous cycle effects on anxiety- and depression-related phenotypes in a two-hit developmental stress model. Front. Mol. Neurosci. 2019, 12, 1-15. [CrossRef] [PubMed]

99. Lébron-Milad, K.; Tsareva, A.; Ahmed, N.; Milad, M.R. Sex differences and estrous cycle in female rats interact with the effects of fluoxetine treatment on fear extinction. Behav. Brain Res. 2013, 253, 217-222. [CrossRef]

100. Eskelund, A.; Budac, D.P.; Sanchez, C.; Elfving, B.; Wegener, G. Female flinders sensitive line rats show estrous cycle-independent depression-like behavior and altered tryptophan metabolism. Neuroscience 2016, 329, 337-348. [CrossRef] 
101. Stukalin, Y.; Lan, A.; Einat, H. Revisiting the validity of the mouse tail suspension test: Systematic review and meta-analysis of the effects of prototypic antidepressants. Neurosci. Biobehav. Rev. 2020, 112, 39-47. [CrossRef]

102. Griebel, G.; Belzung, C.; Perrault, G.; Sanger, D.J. Differences in anxiety-related behaviours and in sensitivity to diazepam in inbred and outbred strains of mice. Psychopharmacology 2000, 148, 164-170. [CrossRef]

103. Komada, M.; Takao, K.; Miyakawa, T. Elevated plus maze for mice. J. Vis. Exp. 2008, e1088. [CrossRef]

104. Lister, R.G. The use of a plus-maze to measure anxiety in the mouse. Psychohparmacology 1987, 92, 180-185. [CrossRef]

105. Liebenberg, N.; Joca, S.; Wegener, G. Nitric oxide involvement in the antidepressant-like effect of ketamine in the Flinders sensitive line rat model of depression. Acta Neuropsychiatr. 2014, 27, 90-96. [CrossRef]

106. Monleon, S.; D'Aquila, P.S.; Parra, A.; Simon, V.M.; Brain, P.F.; Willner, P. Attenuation of sucrose consumption in mice by chronic mild stress and its restoration by imipramine. Psychopharmacology 1995, 117, 453-457. [CrossRef] [PubMed]

107. Bespalov, A.; Michel, M.C.; Steckler, T. Good Research Practice in Pharmacology and Biomedicine; Springer: Cham, Switzerland, 2020; ISBN 9783030336554.

108. Carobrez, A.P.; Bertoglio, L.J. Ethological and temporal analyses of anxiety-like behavior: The elevated plus-maze model 20 years on. Neurosci. Biobehav. Rev. 2005, 29, 1193-1205. [CrossRef]

109. Sales, A.J.; Biojone, C.; Terceti, M.S.; Guimarães, F.S.; Gomes, M.V.M.; Joca, S.R.L. Antidepressant-like effect induced by systemic and intra-hippocampal administration of DNA methylation inhibitors. Br. J. Pharmacol. 2011, 164, 1711-1721. [CrossRef]

110. Can, A.; Dao, D.T.; Terrillion, C.E.; Piantadosi, S.C.; Bhat, S.; Gould, T.D. The tail suspension test. J. Vis. Exp. 2011, e3769. [CrossRef] [PubMed]

111. Prendergast, B.J.; Onishi, K.G.; Zucker, I. Female mice liberated for inclusion in neuroscience and biomedical research. Neurosci. Biobehav. Rev. 2014, 40, 1-5. [CrossRef] [PubMed]

112. Ribeiro, D.E.; Müller, H.K.; Elfving, B.; Eskelund, A.; Joca, S.R.L.; Wegener, G. Antidepressant-like effect induced by P2 $\times 7$ receptor blockade in FSL rats is associated with BDNF signalling activation. J. Psychopharmacol. 2019, 33, 1436-1446. [CrossRef]

113. Pereira, V.S.; Joca, S.R.L.; Harvey, B.H.; Elfving, B.; Wegener, G. Esketamine and rapastinel, but not imipramine, have antidepressant-like effect in a treatment-resistant animal model of depression. Acta Neuropsychiatr. 2019, 31, 258-265. [CrossRef]

114. Becker, J.B.; Prendergast, B.J.; Liang, J.W. Female rats are not more variable than male rats: A meta-analysis of neuroscience studies. Biol. Sex Differ. 2016, 7, 1-7. [CrossRef]

115. Faul, F.; Erdfelder, E.; Lang, A.G.; Buchner, A. G*Power 3: A felixble statistical power analysis program for the social, behavioral, and biomedical sciences. Behav. Res. Methods 2007, 39, 175-191. [CrossRef] [PubMed]

116. Tillmann, S.; Happ, D.F.; Mikkelsen, P.F.; Geisel, J.; Wegener, G.; Obeid, R. Behavioral and metabolic effects of Sadenosylmethionine and imipramine in the Flinders Sensitive Line rat model of depression. Behav. Brain Res. 2019, 364, 274-280. [CrossRef] [PubMed]

117. Silote, G.P.; Gatto, M.C.; Eskelund, A.; Guimarães, F.S.; Wegener, G.; Joca, S. Strain, sex, and time dependent antidepressant-like effects of cannabidiol. Preprints 2021, 2021100347. [CrossRef] 